Journal of Research in Interprofessional

Practice and

Education

Vol. 6.1

June 2016
Journal of Research in Interprofessional Practice and Education (JRIPE)

Vol. 6.1

(C) 2016

Corresponding author: Michael W. Bentley. Email: Michael.Bentley

@utas.edu.au

\section{The Use of a Modified Delphi Technique to Inform the Development of Best Practice in Interprofessional Training for Collaborative Primary Healthcare}

\author{
Michael W. Bentley, BSc, MA, DrPH; \\ Rohan Kerr, MBBS, FRACGP, JCCA (Anaes), FARGP; \& \\ Susan Powell, BSW, GradCert (Health Services Management)
}

\begin{abstract}
Background: Primary healthcare (PHC) education and training is directed to a diverse range of health professionals at undergraduate, postgraduate, and professional levels. Increasing emphasis is being placed on PHC professionals working together in delivering better care and improving patient outcomes. This article reports on using a modified Delphi technique to determine the level of consensus on a series of statements across four domains of interprofessional education (IPE) for collaborative practice: big picture, organization, capabilities, teaching, and learning.

Methods and Findings: The modified Delphi technique used three Delphi rounds: the first round comprising workshops, interviews, or online survey; the remaining rounds used online surveys. A panel of $56 \mathrm{PHC}$ medical, nursing, allied health, and workforce experts participated. There was consensus on a set of capabilities for interprofessional learning outcomes and on a range of teaching and learning strategies. Areas for further consideration included identifying interprofessional training opportunities through continuing professional development, and tailoring team-based approaches to diverse PHC settings.

Conclusion: The modified Delphi technique used in this project demonstrated a successful engagement of a heterogeneous panel of PHC experts. The principles of IPE for collaborative practice and strategies for delivering interprofessional training could apply across various PHC settings.

Keywords: Primary healthcare; Interprofessional workforce training; Continuing professional development
\end{abstract}

\section{Introduction}

Primary healthcare services, such as health promotion/illness prevention, care for the sick and injured, mental health, and allied health services, are considered necessary for good health outcomes in a community [1]. The provision of these primary healthcare services, through general practices, community health services, and other non-government agencies, requires a diverse range of health professionals, including general practitioners (GPs), nurses, and allied health professionals, who are increasingly expected to work together in delivering patient care [2]. There is no single approach to education and training needed to support interprofessional, collabora- 
2

Delphi Technique in Interprofessional Training

Bentley, Kerr, \& Powell

Journal of Research in Interprofessional Practice and Education

Vol. 6.1

June 2016 tive, and integrated primary health care [3]. Hammick, Freeth, Koppel, Reeves, and Barr [4] report that although:

Interprofessional education is generally well received, enabling knowledge and skills necessary for collaborative working to be learnt; it is less able to positively influence attitudes and perceptions towards others in the service delivery team [p. 735].

However, "detailed planning, stakeholder enthusiasm and commitment appear to be essential to the success of interprofessional continuing education" [5, p. 111]. Moreover, there are many systemic and organizational determinants of successful collaboration, including the educational and professional systems [6]. Several issues from the organizational change literature are relevant to the implementation of initiatives in interprofessional education for collaborative practice:

At the level of the individual: the existence of strong professional cultures and the need to motivate change. At the level of the organization, the context of and leadership for interprofessional education (IPE) and collaborative practice are relevant. At the system level, a discussion of incremental versus radical forces for change is particularly germane [7, p. 177].

Although interprofessional education is seen as a response to a fragmented health system [2], there are research gaps and more evidence is needed [8]. Many questions about interprofessional education and teamwork, such as when to educate, who to educate, and how to educate, remain unanswered and open to future research [9]. In Australia, for instance, the training of primary healthcare professionals occurs at several levels (undergraduate, postgraduate, continuing professional development) and many organizations are involved. Meeting continuing professional development standards is a registration requirement for many medical, nursing, and allied health professionals.

\section{Context}

In Tasmania, the evidence for integrated, collaborative, and interprofessional approaches to primary healthcare training is mainly anecdotal. General Practice Training Tasmania (GPTT) and Tasmania Medicare Local undertook a partnership project that aimed to develop a strategic picture of the steps necessary for multiple primary healthcare workforce training providers to align key aspects of their training with the common aims of integration, collaboration, and teamwork. GPTT is the sole accredited regional training organization for medical graduates who wish to qualify for registration as a general practitioner (also known as a primary care physician or family physician) in Tasmania. Tasmania Medicare Local is now Primary Health Tasmania, a network organization funded by the Australian government to promote a coordinated, primary care-focused health system; this includes services to support health professionals and other people working in primary health care, including professional development, training, and networking opportunities. 
Delphi Technique in Interprofessional Training

Bentley, Kerr, \& Powell

Journal of Research in Interprofessional Practice and Education

Vol. 6.1

June 2016

\section{Journal of Research in Interprofessional Practice and Education}

For the purpose of clarity, the following definitions will be used in this article [10]:

- Interprofessional education (IPE): “occasions when two or more professions learn from and about each other to improve collaboration and the quality of care." [p. 24]

- Collaborative patient-centred practice: "is designed to promote the active participation of each discipline in patient care. It enhances patient and family centred goals and values, provides mechanisms for continuous communication among caregivers, and optimizes staff participation in clinical decision making within and across disciplines fostering respect for disciplinary contributions of all professionals." [p. 24]

The research question was: What features of interprofessional education for collaborative practice could inform the development of an integrated roadmap to best practice primary healthcare training in Tasmania? This article reports on the use of a modified Delphi technique to determine the level of consensus on a series of statements across four domains of interprofessional education for collaborative practice-the big picture, capabilities, teaching and learning, and organization [11].

\section{Methods}

The Delphi technique is "a structured process that uses a series of questionnaires or 'rounds' to gather information which are continued until 'group' consensus is reached" [12, p. 206]. We chose the Delphi technique because it is an appropriate method for topics where there is limited evidence and wide opinion [13], such as interprofessional, collaborative, and integrated primary healthcare. Furthermore, the method is also suitable for when participants work in diverse geographic locations and where there is a need to ensure that individual opinion does not dominate the process of seeking consensus across a wide group of experts [13]. The Delphi technique has been used in areas related to our study [1,14-17]. To inform the Delphi process, a rapid review (see Appendix 1) of the literature (a search of PubMed) was used to identify reviews of primary healthcare training that featured integrated, collaborative, interprofessional approaches. Search terms included integration, collaboration, multidisciplinary, interdisciplinary, interprofessional, primary (health) care, general practice, and team (work). The PubMed database was searched for reviews written in English and published between January 2001 and November 2013. Rapid reviews are commonly used when there are limited time and resource constraints [18]. As this project was conducted over a twelve-month timeframe, a more rigorous systematic review was not feasible [19]. The streamlined methods used (published reviews, limited inclusion criteria by date and language, one researcher (MB) conducting the review) are common approaches to rapid reviews [19].

Thirty-three reviews were identified (see Appendix 1). Reference lists of these reviews were searched for relevant studies, perspectives, and models. Framework analysis [20], a qualitative data analysis method that generates a matrix of cases and themes, was used to summarize these papers and categorize the themes against the 
4

Delphi Technique in Interprofessional Training

Bentley, Kerr, \& Powell

Journal of Research in Interprofessional Practice and Education

Vol. 6.1

June 2016 findings (positive, negative, inconclusive, propositions to be tested). This analysis was discussed and agreed upon by the research team (MB, RK, SP) and used to develop statements about interprofessional capabilities and education strategies to test for consensus using the modified Delphi consensus technique.

To select a heterogeneous panel of primary healthcare stakeholders for the Delphi technique, a criterion sampling strategy was used [21]. The criteria comprised: state wide and regional representation; a mix of medical, nursing, allied health professionals and workforce specialists; perspectives from academics, health service managers, and practitioners. The project's reference group provided important assistance. Potential participants were sent a letter of invitation via email or post with a participant information sheet and consent form. A modified Delphi technique was used. In a modified Delphi technique, the first round uses focus groups and/or interviews to generate initial interest and commitment to the process [13]. Our modified Delphi consensus technique had three rounds.

In Round 1, three workshops were conducted in the northwest, north, and south of Tasmania. The workshops lasted for approximately one hour. Participants were asked not to disclose details of the discussion in the workshops in order to protect participants' anonymity and maintain confidentiality of the information gathered. Participants who were unable to attend a workshop were offered the opportunity of an interview with the research officer or completion of an online survey. The interviews took approximately twenty to thirty minutes and were conducted by telephone or in person. The workshops, interviews, and online survey used two open-ended questions: 1) What are the training gaps that exist in the current and future primary healthcare workforce environment in Tasmania? 2) What are possible integrated solutions or models (that use interprofessional approaches to collaborative practice) to address these gaps?

In Round 2 of the project, participants were asked to rate and comment on a series of statements in relation to interprofessional education for collaborative practice. There were thirty-three statements, which were developed from the findings of the focused scan of the international literature, and thematic analysis [22] of the workshops, interviews, and survey conducted in Round 1. The statements were grouped under four sections, using a conceptual framework developed for the Australian context [11]: 1) Big picture (the why?); 2) Capabilities (the what?); 3) Teaching \& learning (the how?); and 4) Organization (the where?). This framework captured the themes from Round 1. Five-point Likert items were used for each of the statements and participants were asked to rate each statement. Statements asked for level of agreement ("strongly disagree," "disagree," "neither disagree nor agree," "agree," "strongly agree"), level of importance ("not at all important," "unimportant," "neither unimportant nor important," “important," "very important") or level of usefulness ("not at all useful," "not very useful," "neither not useful nor useful," "somewhat useful," "very useful"). Participants were also asked to provide reasons for their ratings of each statement via a comments box. In addition, participants were asked to identify the main priority focus areas where interprofessional education for collaborative practice was needed. See Appendix 2 for the complete list of Round 2 survey statements. 
5

Delphi Technique in Interprofessional Training

Bentley, Kerr, \& Powell

Journal of Research in Interprofessional Practice and Education

Vol. 6.1

June 2016
There are no agreed guidelines on what constitutes consensus in a Delphi study [12]. Consensus measurement includes level of agreement, median scores, and interquartile ranges [23]. In this study we used all three types of measurements as they are all commonly used in health research [12]. We applied the following criteria for consensus: $\geq 70$ percent of participants either "agree" or "strongly agree" with the statement (or rated the statement as "important" or "very important," "somewhat useful" or "very useful") and median score $\geq 4$ and interquartile range $\leq 1$. In Round 3, the median score needed to be $\geq 3$, as Likert items used in this round were changed from a five-point scale to a four-point scale, removing the middle (neutral) option to elicit an opinion for or against a statement [24].

In Round 3 of the project, participants were asked to rate and comment on the statements in relation to interprofessional education for collaborative practice that did not achieve consensus in Round 2. Participants received the median score, level of agreement/disagreement and comments on the statement from Round 2. Participants were also given the results for the statements that reached consensus. In this round four-point Likert items were used. The middle response, e.g., "neither disagree nor agree," was removed to determine the level of agreement or disagreement. Participants were asked to tick the N/A box if they had no opinion on a statement. Participants were also asked to comment on what interprofessional education is needed for collaborative practice in the priority areas identified in Round 2. See Appendix 3 for the complete list of Round 3 survey statements.

The three rounds were conducted between April and August 2014. Surveys were developed and administered using the SurveyMonkey ${ }^{\circledast}$ web-based format, which has been shown to increase data quality and response rates [25]. Additionally, we aimed to minimize non-response in the three rounds by using personalized emails and two email reminders [26]. Responses were analyzed using Microsoft Excel 2013 ${ }^{\circledR}$. All participants were sent emails with links to the surveys. Ethics approval was obtained from the Tasmania Social Sciences Human Research Ethics Committee.

\section{Results}

We identified 477 key stakeholders from organizations with a primary healthcare workforce-training role in Tasmania. This large list included 244 medical practitioners working in general practice (114 GP supervisors and 130 GP registrars currently training for vocational registration as a GP); GPs receive many requests to participate in research and we anticipated a low rate of participation from this group [27]. The response rates were: Allied Health-60 percent; Nursing-21 percent; General Practice-6 percent; and Other-42 percent (the "Other" category mainly comprised university academics and program managers from local primary healthcare organizations). The final Delphi panel comprised 56 members.

Round 1: Sixteen people participated in the workshops. Six additional face-toface/telephone interviews were conducted. An online survey was sent to 35 participants with 22 responses (63\% response rate). The overall participation rate in Round 1 was 77 percent. An online survey was used in Rounds 2 and 3. The response rate to the Round 2 online survey was 74 percent ( 42 respondents). The response rate to 


\section{JRIPE}

6

Delphi Technique in Interprofessional Training

Bentley, Kerr, \& Powell

the Round 3 online survey was 73 percent (41 respondents). The results from Round 2 and Round 3 are detailed in Table 2 and Table 3, respectively. Results in each of the four sections - the why, the what, the how, and the where-are discussed in turn.

Table 1 details the characteristics of the Delphi panel.

\begin{tabular}{|c|c|}
\hline Number of participants & $56^{*}$ \\
\hline Categories & $\begin{array}{l}\text { Allied health } 15 \text { (27\%) } \\
\text { General practice } 19(34 \%) \\
\text { Nursing } 7 \text { (13\%) } \\
\text { Other } 15(27 \%)\end{array}$ \\
\hline Disciplines and professions & $\begin{array}{l}\text { Chiropractic } \\
\text { Dental } \\
\text { Diabetes nurse education } \\
\text { General practice } \\
\text { Mental health } \\
\text { Nursing } \\
\text { Occupational therapy } \\
\text { Optometry } \\
\text { Paramedicine } \\
\text { Psychology } \\
\text { Social work } \\
\text { Speech pathology }\end{array}$ \\
\hline Organizations & $\begin{array}{l}\text { Allied health professional bodies } \\
\text { Department of Health and Human Services (Tasmania) } \\
\text { General Practice Training Tasmania } \\
\text { Non-government health agencies } \\
\text { Tasmania Medicare Local } \\
\text { University of Tasmania }\end{array}$ \\
\hline Geographic spread & $\begin{array}{l}\text { North } 10(18 \%) \\
\text { Northwest } 6 \text { (11\%) } \\
\text { South } 16(29 \%) \\
\text { Statewide } 23(41 \%) \\
\text { National } 1(2 \%)\end{array}$ \\
\hline Gender & $\begin{array}{l}\text { Male } 15(27 \%) \\
\text { Female } 41(73 \%)\end{array}$ \\
\hline
\end{tabular}

Journal of Research in Interprofessional Practice and Education

Vol. 6.1

June 2016

*Originally 57 members - two members left their positions during the process, one joined after Round 1. 
7

Delphi Technique in Interprofessional Training

Bentley, Kerr, \& Powell
Journal of Research in Interprofessional

Practice and Education

Vol. 6.1

June 2016
Table 2: Delphi consensus on interprofessional training for collaborative practice (Round 2)

\begin{tabular}{|c|c|c|c|}
\hline Dimension & Consensus & Median & $\begin{array}{l}\text { Interquartile } \\
\text { range }\end{array}$ \\
\hline \multicolumn{4}{|l|}{ 1. Big picture (the why?) } \\
\hline $\begin{array}{l}\text { Interprofessional training needs to be integrated across primary, sec- } \\
\text { ondary and tertiary levels of the health system. }\end{array}$ & $95 \%$ & 4 & $4-5$ \\
\hline $\begin{array}{l}\text { More evidence is needed on the organisational and systemic determi- } \\
\text { nants of interprofessional education for collaborative practice. }\end{array}$ & $64 \%$ & 4 & $3-5$ \\
\hline $\begin{array}{l}\text { The curriculum at the University of Tasmania is too crowded to } \\
\text { expand interprofessional education for primary health. }\end{array}$ & $24 \%$ & 3 & $2-4$ \\
\hline $\begin{array}{l}\text { The lack of undergraduate Allied Health education at the University of } \\
\text { Tasmania limits opportunities for interprofessional education. }\end{array}$ & $64 \%$ & 4 & $3-5$ \\
\hline $\begin{array}{l}\text { The lack of postgraduate training in Tasmania for some disciplines } \\
\text { limits opportunities for interprofessional education. }\end{array}$ & $57 \%$ & 4 & $3-5$ \\
\hline $\begin{array}{l}\text { Existing requirements for continuing professional development limit } \\
\text { opportunities for interprofessional training. }\end{array}$ & $26 \%$ & 3 & $3-3.75$ \\
\hline \multicolumn{4}{|l|}{ 2. Capabilities (the what?) } \\
\hline \multicolumn{4}{|l|}{ Interprofessional learning outcomes relating to teamwork: } \\
\hline Knowledge of, and skills for, teamwork (98\% consensus) & $98 \%$ & 5 & $4-5$ \\
\hline $\begin{array}{l}\text { Knowledge and understanding of the different roles, boundaries, } \\
\text { responsibilities and expertise of health professionals }\end{array}$ & $100 \%$ & 5 & $4-5$ \\
\hline Being able to challenge misconceptions in relations to roles & $90 \%$ & 5 & $4-5$ \\
\hline \multicolumn{4}{|l|}{ Interprofessional learning outcomes related to communication } \\
\hline Ability to communicate effectively with other health professional students & $95 \%$ & 5 & $4-5$ \\
\hline Awareness of difference in professionals' language & $98 \%$ & 5 & $4-5$ \\
\hline Ability to express one's opinions to others involved with care & $100 \%$ & 5 & $5-5$ \\
\hline \multicolumn{4}{|l|}{ Interprofessional learning outcomes relating to learning/reflection } \\
\hline Ability to reflect critically on one's own relationship within a team & $95 \%$ & 4 & $4-5$ \\
\hline Ability to transfer interprofessional learning to the clinical setting & $97 \%$ & 5 & $4-5$ \\
\hline The central role of the patient in collaborative care & $100 \%$ & 5 & $4-5$ \\
\hline Understanding of patient safety issues & $95 \%$ & 5 & $4-5$ \\
\hline
\end{tabular}


Table 2: (continued)

Delphi Technique in Interprofessional Training

Bentley, Kerr, \& Powell
Journal of Research in Interprofessional

Practice and Education

Vol. 6.1

June 2016

\begin{tabular}{|c|c|c|c|}
\hline Dimension & Consensus & Median & $\begin{array}{l}\text { Interquartile } \\
\text { range }\end{array}$ \\
\hline \multicolumn{4}{|l|}{ Interprofessional learning outcomes relating to ethics/attitudes } \\
\hline Ability to acknowledge views and ideas of other professionals & $97 \%$ & 5 & $4-5$ \\
\hline Understanding the ethical issues relating to teamwork & $97 \%$ & 5 & $4-5$ \\
\hline \multicolumn{4}{|l|}{ 3. Teaching \& Learning (the how?) } \\
\hline Practice-based, small group learning programs & $92 \%$ & 5 & $4-5$ \\
\hline Simulation-based, interprofessional learning & $93 \%$ & 5 & $4-5$ \\
\hline A team-based approach tailored to primary healthcare/general practice & $95 \%$ & 5 & $4-5$ \\
\hline Issue/problem-based interprofessional learning & $95 \%$ & 5 & $4-5$ \\
\hline Case-based interprofessional learning & $95 \%$ & 5 & $4-5$ \\
\hline Clinical audits $^{\#}$ & $75 \%$ & 4 & $3.75-5$ \\
\hline Student-led case conferencing & $68 \%$ & 4 & $3-4$ \\
\hline \multicolumn{4}{|l|}{ 4. Organisation (the where?) } \\
\hline Lecture and seminar based education sessions are still important. & $67 \%$ & 4 & 3-4 \\
\hline Interprofessional teams need to be collocated to function effectively. & $70 \%$ & 4 & 3-5 \\
\hline $\begin{array}{l}\text { Clarity on the role of leadership in an interprofessional team is criti- } \\
\text { cal for effective team functioning. }\end{array}$ & $90 \%$ & 4.5 & $4-5$ \\
\hline $\begin{array}{l}\text { Virtual communities of practice can overcome isolation for primary } \\
\text { healthcare practitioners in rural and remote areas. }\end{array}$ & $77 \%$ & 4 & $4-4.5$ \\
\hline $\begin{array}{l}\text { Internet-based courses can provide meaningful interaction for pri- } \\
\text { mary healthcare practitioners. }\end{array}$ & $72 \%$ & 4 & $3-4$ \\
\hline $\begin{array}{l}\text { A central training calendar for primary healthcare/general practice is } \\
\text { important. }\end{array}$ & $84 \%$ & 4 & $4-4$ \\
\hline $\begin{array}{l}\text { A central directory of educators and supervisors for interprofessional } \\
\text { primary healthcare training is important. }\end{array}$ & $81 \%$ & 4 & $4-5$ \\
\hline
\end{tabular}

\# One participant rated this statement as 'not at all useful' without providing a comment. The research team agreed that this response was ambiguous and accepted the consensus for the statement. 


\section{JRIPE}

9

Delphi Technique in Interprofessional Training

Bentley, Kerr, \& Powell
Table 3: Delphi consensus on interprofessional training for collaborative practice (Round 3)

\begin{tabular}{|c|c|c|c|}
\hline Dimension & Consensus & $\begin{array}{l}\text { Median" } \\
\text { Interqu }\end{array}$ & $\begin{array}{l}\text { artile range } \\
\text { More evidence }\end{array}$ \\
\hline \multicolumn{4}{|l|}{ 1. Big picture (the why?) } \\
\hline $\begin{array}{l}\text { is needed on the organisational and systemic determinants of inter- } \\
\text { professional education for collaborative practice. }\end{array}$ & $68 \%$ & 3 & $2-3$ \\
\hline $\begin{array}{l}\text { The curriculum at the University of Tasmania is too crowded to } \\
\text { expand interprofessional education for primary health. }\end{array}$ & $34 \%$ & 2 & $2-3$ \\
\hline $\begin{array}{l}\text { The lack of undergraduate Allied Health education at the University } \\
\text { of Tasmania limits opportunities for interprofessional education. }\end{array}$ & $49 \%$ & 2 & $2-3$ \\
\hline $\begin{array}{l}\text { The lack of postgraduate training in Tasmania for some disciplines } \\
\text { limits opportunities for interprofessional education. }\end{array}$ & $62 \%$ & 3 & $2-3$ \\
\hline $\begin{array}{l}\text { Existing requirements for continuing professional development } \\
\text { limit opportunities for interprofessional training. }\end{array}$ & $37 \%$ & 2 & $2-3$ \\
\hline \multicolumn{4}{|l|}{ 3. Teaching \& Learning (the how?) } \\
\hline Student-led case conferencing & $82 \%$ & 3 & $3-4$ \\
\hline \multicolumn{4}{|l|}{ 4. Organisation (the where?) } \\
\hline Lecture and seminar based education sessions are still important. & $88 \%$ & 3 & $3-3$ \\
\hline Interprofessional teams need to be collocated to function effectively. & $47 \%$ & 2 & $2-3$ \\
\hline
\end{tabular}

Note: \# The Likert items used in Round 3 were changed from a five-point scale to a four-point scale, removing the middle (neutral) option to elicit an opinion for or against a statement. Participants were asked to tick the N/A box, if they had no opinion on a statement.

Big-picture decisions: The why

The panel agreed that interprofessional training needs to be integrated across primary, secondary, and tertiary levels of the health system. The panel did not reach consensus on whether more evidence on the organizational and systemic determinants of interprofessional education for collaborative practice is required. Comments suggested that IPE for collaborative practice initiatives should proceed, but still required evaluation evidence. Further consideration is needed: 1) to explore opportunities to foster interprofessional education for primary health in the curriculum at the University of Tasmania; 2) to address the lack of undergraduate courses for many allied health professions; 3 ) to identify more opportunities for interprofessional education in postgraduate training; and 4) to maximize opportunities for interprofessional training through continuing professional development. 
Delphi Technique in Interprofessional Training

Bentley, Kerr, \& Powell
Journal of Research in Interprofessional Practice and Education

Vol. 6.1

June 2016
Journal of Research in Interprofessional Practice and Education

\section{Defining and understanding capabilities: The what}

The panel agreed on a set of capabilities for interprofessional learning outcomes relating to:

- Teamwork (knowledge of, and skills for, teamwork; knowledge and understanding of the different roles, boundaries, responsibilities, and expertise of health professionals; and being able to challenge misconceptions in relations to roles);

- Communication (ability to communicate effectively with other health professional students; awareness of difference in professionals' language; and ability to express one's opinions to others involved with care);

- Learning/reflection (ability to reflect critically on one's own relationship within a team; and ability to transfer interprofessional learning to the clinical setting);

- The patient/client (the central role of the patient in collaborative care; and understanding of patient safety issues); and

- Ethics/attitudes (ability to acknowledge views and ideas of other professionals; and understanding the ethical issues relating to teamwork).

The principles of interprofessional training for collaborative practice can be applied to primary healthcare training topics in health areas such as mental health, chronic conditions, emergency medicine, musculoskeletal conditions, use of medicines, and wound management, and for population groups such as Aboriginal health, lesbian, gay, bisexual, transgender, and intersex health, refugee health, women's and children's health, youth health, and the ageing population.

\section{Teaching and learning: The how}

The panel agreed on a range of teaching and learning strategies: a team-based approach tailored to primary healthcare/general practice; case-based interprofessional learning; issue/problem-based interprofessional learning; practice-based, small group learning programs; simulation-based interprofessional learning; student-led case conferencing, and clinical audits.

\section{Organization: The where}

The panel agreed that lecture/seminar sessions are still important for interprofessional training, as they offer opportunities to hear from specialists and network with other health professionals. Coordinating training, via a central training calendar for primary healthcare/general practice and a central directory of educators and supervisors for interprofessional primary healthcare training, was seen as important. This support was qualified by comments attesting to the difficulty of achieving coordination when there are disparate providers of events and training.

The panel agreed that clarity on the role of leadership in an interprofessional team is critical for effective team functioning. However, the panel, while tending to agree in Round 2 that interprofessional teams need to be co-located to function effectively, was evenly split on the statement after Round 3. In Round 2, there was a 20 percent "neu- 
11

Delphi Technique in Interprofessional Training

Bentley, Kerr, \& Powell
Journal of Research in Interprofessional Practice and Education

Vol. 6.1

June 2016 tral" response (i.e., neither agree nor disagree). In Round 3, 22 percent elected for the "not applicable" option. However, the reasons for the shift from 70 percent support in Round 2 to 47 percent support in Round 3 are not clear. Responses in the comments box that followed the statement indicated that while it was seen as desirable for interprofessional teams to be co-located (e.g., for patient access, proximity), co-location was not always possible (e.g., remote sites). Some panel members also suggested communication and respect as key factors to effective team functioning.

\section{Discussion}

The panel agreed on "the what" (the principles that apply to interprofessional training for collaborative practice) and "the how" (ways to deliver interprofessional training). These results are, perhaps, not surprising. The principles of interprofessional education have been well articulated $[2,28]$. Ways to deliver interprofessional training in general practice and primary healthcare have been described in the literature, which was used to inform this Delphi process. In particular, small-group learning [29] and simulation-based training [30] are well established in general practice. Casebased learning [31] and problem-based learning [32] are widely used for students and health professionals. Students can also work together using case conferencing [33] and clinical audits [34] as mechanisms for interprofessional learning.

Some of the questions on "the why" and "the where" of interprofessional training for collaborative practice require further consideration in the context of the local delivery of primary health education and training. A recent scoping paper identified three levels of interventions for interprofessional collaboration: interprofessional training at the individual level; interprofessional interventions at the practice-based level; and interventions at the organization level [35]. It is at the organizational level where the influence of context (local and "big picture") is important $[10,11,36]$. Tasmania has one university, one regional training organisation for GP registrars, one Primary Health Network [37], and one Tasmanian Health Service [38], which offers opportunities for a coordinated approach to interprofessional education and training.

At the practice-based level, distance need not be a barrier to interprofessional learning [39], yet there are implications for collaborative practice where services are dispersed. The shift in opinion on whether interprofessional teams need to be colocated to function effectively was a notable finding in the Delphi process. There are primary healthcare services in Tasmania where teams are co-located, but also many isolated services that depend on visiting health professionals [40,41]. Integrated care centres have been set up by the Tasmanian health department to accommodate a range of health services across both primary and acute care [40]. Co-locating services do not always mean that professionals in such services will necessarily work together [42]. Factors such as team premises, size and composition of the team, and organizational support are important structures needed for successful team-working, as well as processes that include team meetings, clear goals and objectives, and audit [43]. A review of nurse practitioners and medical practitioners showed it takes time to develop collaborative practice [44]. Whether teams are co-located or dispersed, communication, support, and respect are key factors for health professionals $[6,45]$. 
12

Delphi Technique in Interprofessional Training

Bentley, Kerr, \& Powell
Journal of Research in Interprofessional Practice and Education

Vol. 6.1

June 2016
At the individual level, overcoming isolation is important. In the rural and regional context, strategies such as virtual communities of practice have been used for GP registrars [46]. However, general practitioners still prefer face-to-face learning for continuing medical education [47]. There are questions about how to provide meaningful interaction in internet-based education [48] and integrating face-to-face and e-learning methods (i.e., blended learning) across health education requires more evidence [49].

\section{Reflections on the use of the modified Delphi technique}

Self-selection, recruitment, and non-responder bias, researcher bias, and a drop off in participation are all limitations of the Delphi technique $[12,13]$.

We had a low response rate from general practice. However, the Delphi panel included several GP supervisors and GP registrars. The main group missing from the invitation list was Practice Managers, who are usually non-medical staff. There was a higher response rate from medical educators $(41 \%)$. The only allied health professions not represented on the panel were dietetics and physiotherapy (in Tasmania, there are no local undergraduate or postgraduate courses available in these professions). In nursing, the response rate for nurses involved in education was higher than for those involved in management (31\% c.f. $20 \%)$. Given that this was a study concerned with health education and training, it is not surprising that the response rates were higher from people directly involved in this area. However, social desirability bias was minimized by the use of anonymous web-based surveys in Rounds 2 and 3 . The Delphi technique, like other non-probability sampling techniques, "does not ensure accurate representation and results cannot be generalized to other settings or to a wider population" [11, p. 208]. Therefore, a limitation of this study is that it is specific to the Tasmanian context. However, the modified Delphi technique could be adapted and applied to other primary healthcare settings across and outside Australia where an interprofessional approach is sought.

While there is no standard sample size for a Delphi panel, most Delphi panels in health research use a sample size between 10 and 100 participants [13]. A recent Australian study seeking interdisciplinary consensus on academic program structure identified fifty-three academics as key stakeholders [15]. The large number of participants $(N=56)$ on our panel improved the reliability of the study.

To address the potential that participants may know each other, which can make anonymity difficult, we used the concept of quasi-anonymity [50]. That is:

It is often the case that panel members know each other, but they cannot attribute responses to any one member. It is like being in an elite 'expert' club where the membership is known but they do not meet face to face to discuss the issues. In fact, knowing that you are a member of an exclusive club may help motivate panellists to participate $[13$, p. 10].

We addressed some of the threats to the validity of the study by maintaining a high response rate $(\geq 73 \%)$ in each round of the study and by using researcher triangula- 
Delphi Technique in Interprofessional Training

Bentley, Kerr, \& Powell
Journal of Research in Interprofessional Practice and Education

Vol. 6.1

June 2016
Journal of Research in Interprofessional Practice and Education

tion to avoid researcher bias [13]. Logistical constraints (time and resources) limited the Delphi process to three rounds. It is unclear whether further rounds would have altered the level of consensus on the remaining statements from Round 3.

The number of items on Likert scales used in the Delphi technique varies. While a nine-point scale has been recommended [51], it also causes confusion [52]. One study found that five- or seven-point scales are "likely to produce slightly higher mean scores relative to the highest possible attainable score, compared to that produced from a 10point scale" [53, p. 61]. We chose the five-point scale because it was the most common scale used in studies similar to ours [1,14-16].

\section{Implications for further research}

Australia is not alone in its focus on general practice as a central provider of primary healthcare services [54]. The move toward more teamwork in general practice is widely recognized across Europe [55] and teamwork has been shown to improve job satisfaction in Australian general practice [56]. Moreover, in Canadian family practices, the commitment by and leadership of GPs is crucial to the successful implementation of interprofessional and collaborative care [57].

Two areas for further consideration include research on tailoring team-based approaches to diverse PHC settings, and identifying interprofessional training opportunities through continuing professional development. As this study focuses on the education side of interprofessional training for collaborative practice, the views of patient are absent. Further research is also needed on how patients/clients can be integrated into the collaborative healthcare team [58].

\section{Conclusion}

The modified Delphi technique, as used in this study, demonstrated a successful engagement of a heterogeneous panel of stakeholders in primary health education and training. While some of the findings are specific to the Tasmanian context, the agreed principles reflect those of the Centre for the Advancement of Interprofessional Education [28]. The agreed ways of delivering interprofessional training for collaborative practice could apply across diverse primary healthcare settings, such as community health and general practice [6].

\section{Acknowledgements}

This research was part of a partnership project of General Practice Training Tasmania and Tasmania Medicare Local. MB was employed by GPTT to conduct the project. RK is an employee of GPTT. SP is an employee of Primary Health Tasmania. The information and discussion do not necessarily reflect the views or policy of General Practice Training Tasmania or Primary Health Tasmania.
Abbreviations
GP General Practitioner
GPTT General Practice Training Tasmania
IPE Interprofessional Education 
14

Delphi Technique in Interprofessional Training

Bentley, Kerr, \& Powell
Journal of Research in Interprofessional Practice and Education

Vol. 6.1

June 2016

\section{References}

1. Thomas, Susan L., Wakerman, John, \& Humphreys, John S. (2014). What core primary health care services should be available to Australians living in rural and remote communities? BMC Family Practice, 15, 143.

2. World Health Organization. (2010). Framework for action on interprofessional education \& collaborative practice. Geneva, $\mathrm{CH}$ : WHO.

3. Freeth, Della, \& Reeves, Scott (2004). Learning to work together: Using the presage, process, product (3P) model to highlight decisions and possibilities. Journal of Interprofessional Care, 18(1), 43-56.

4. Hammick, Marilyn, Freeth, Della, Koppel, Ivan, Reeves, Scott, \& Barr, Hugh (2007). A best evidence systematic review of interprofessional education: BEME Guide no. 9. Medical Teacher, 29(8), 735-751.

5. Davidson, Megan, Smith, Robyn A., Dodd, Karen J., Smith, Jenni S., \& O’Laughlan, Meredith J. (2008). Interprofessional pre-qualification clinical education: A systematic review. Australian Health Review, 32(1), 111-120.

6. San Martinez-Rodriguez, Leticia, Beaulieu, Marie-Dominique, D'Amour, Danielle, \& FerradaVidela, Marcela (2005). The determinants of successful collaboration: A review of theoretical and empirical studies. Journal of Interprofessional Care, 19(supplement 1), 132-147.

7. Ginsburg, Liane, \& Tregunno, Deborah (2005). New approaches to interprofessional education and collaborative practice: Lessons from the organizational change literature. Journal of Interprofessional Care, 19(supplement 1), 177-187.

8. Reeves, Scott, Perrier, Laure, Goldman, Joanne, Freeth, Della, \& Zwarenstein, Merrick (2013). Interprofessional education: Effects on professional practice and healthcare outcomes (update). Cochrane Database of Systematic Reviews, No. 3, Art. No. CD002213. URL: http://onlinelibrary .wiley.com/doi/10.1002/14651858.CD002213.pub3/full [November 12, 2015]

9. Hall Pippa, \& Weaver, Lynda (2001). Interdisciplinary education and teamwork: A long and winding road. Medical Education, 35(9), 867-875.

10. Oandasan, Ivy, \& Reeves, Scott (2005). Key elements for interprofessional education. Part 1: the learner, the educator and the learning context. Journal of Interprofessional Care, 19 (supplement 1), 21-38.

11. Lee, Alison, Steketee, Carole, Rogers, Gary, \& Moran, Monica (2013). Towards a theoretical framework for curriculum development in health professional education. Focus on Health Professional Education, 14(3), 64-70.

12. Keeney, Sinead, Hasson, Felicity, \& McKenna, Hugh (2006). Consulting the oracle: Ten lessons from using the Delphi technique in nursing research. Journal of Advanced Nursing, 53(2), 205-212.

13. Keeney, Sinead, Hasson, Felicity, \& McKenna, Hugh (2010). The Delphi technique in nursing and health research. Chichester, UK: Wiley.

14. Junod Perron, Noelle, Cerutti, Bernard, Picchiottino, Patricia, Empeyta, Sebastien, Cinter, Francoise, \& van Gessel, Elisabeth (2014). Needs assessment for training in interprofessional skills in Swiss primary care: A Delphi study. Journal of Interprofessional Care, 28(3), 273-275.

15. O’Keefe, Maree, Elshaugh, Adam, Burgess, Teresa, Peirce, Eleanor, \& Nettlebeck, Ted (2012). Use of the Delphi technique to facilitate interdisciplinary consensus on academic program structure. Focus on Health Professional Education, 14(1), 55-66.

16. Attieh, Randa, Gagnon, Marie-Pierre, Estabrooks, Carole A., Légaré, France, Ouimet, Mathieu, Vazquez, Patricia, \& Nuño, Roberto (2014) Organizational readiness for knowledge translation in chronic care: A Delphi study. BMC Health Services Research, 14(1), 534.

17. McKenna, Hugh, Keeney, Sinead, \& Bradley, Martin (2003). Generic and specialist nursing roles: Views of community nurses, general practitioners, senior policymakers and members of the public. Health \& Social Care in the Community, 11(6), 537-545.

18. Ganann, Rebecca, Ciliska, Donna, \& Thomas, Helen (2010). Expediting systematic reviews: Methods and implications of rapid reviews. Implementation Science, 5(1), 56.

19. Tricco, Andrea C., Antony, Jesmin, Zarin, Wasifa, Strifler, Lisa, Ghassemi, Marco, Ivory, John, Perrier, Laure, Hutton, Brian, Moher, David, \& Straus, Sharon E. (2015). A scoping review of rapid review methods. BMC Medicine, 13(1), 1.

20. Ritchie, Jan, \& Spencer, Liz (2002). Qualitative data analysis for applied policy research. In: A. Michael Huberman, \& Matthew B. Miles (Eds), The qualitative researcher's companion, pp. 305-329. Thousand Oaks, CA: Sage.

21. Hasson, Felicity, Keeney, Sinead, \& McKenna, Hugh (2000). Research guidelines for the Delphi survey technique. Journal of Advanced Nursing, 32(4), 1008-1015.

22. Miles, Matthew B., \& Huberman, A. Michael (1994). Qualitative data analysis (2nd ed.). Thousand Oaks, CA: Sage. 
15

Delphi Technique in Interprofessional Training

Bentley, Kerr, \& Powell
23. von der Gracht, Heiko A. (2012). Consensus measurement in Delphi studies: Review and implications for future quality assurance. Technological Forecasting and Social Change, 79, 1525-1536.

24. Garland, Ron (1991). The mid-point on a rating scale: Is it desirable? Marketing Bulletin, 2 (Research Note 3), 66-70.

25. Gill, Fenella J., Leslie, Gavin D., Grech, Carol, \& Latour, Jos M. (2013). Using a web-based survey tool to undertake a Delphi study: Application for nurse education research. Nursing Education Today, 33(11), 1322-1328.

26. Hsu, Chia-Chien., \& Sandford, Brian A. (2007). Minimizing non-response in the Delphi process: How to respond to non-response. Practical Assessment, Research \& Evaluation, 12, 17.

27. McKinn, Shannon, Bonner, Carissa, Jansen, Jesse, \& McCaffery, Kirsten (2015). Recruiting general practitioners as participants for qualitative and experimental primary care studies in Australia. Australian Journal of Primary Health, 21(3), 354-359.

28. Barr, Hugh, \& Low, Helena (2011). Principles of interprofessional education. Fareham, UK: Centre for the Advancement of Interprofessional Education (CAIPE).

29. Stelter, Klaus, \& Marangoni, Silvana (2011). Small group learning: A general practice program. Australian Family Physician, 40(10), 831-834.

30. van Soeren, Mary, Devlin-Cop, Sandra, MacMillan, Kathleen, Baker, Lindsay, Egan-Lee, Eileen, \& Reeves, Scott (2011). Simulated interprofessional education: An analysis of teaching and learning processes. Journal of Interprofessional Care, 25(6), 434-440.

31. Thistlethwaite, Jill E., Davies, David, Ekeocha, Samilia, Kidd, Jane M., MacDougall, Colin, Matthews, Paul, Purkis, Judith, \& Clay, Diane (2012). The effectiveness of case-based learning in health professional education. A BEME systematic review: BEME Guide No. 23. Medical Teacher, 34(6), e421-e444.

32. Dahlgren, Lars O. (2009). Interprofessional and problem-based learning: A marriage made in heaven? Journal of Interprofessional Care, 2009, 23(5), 448-454.

33. Stew, Graham (2005). Learning together in practice: A survey of interprofessional education in clinical settings in South-East England. Journal of Interprofessional Care, 19(3), 223-235.

34. Chambers, Ruth, \& Wakley, Gill (2005). Clinical audit in primary care: Demonstrating quality and outcomes. Abingdon, UK: Radcliffe Publishing.

35. Goldman, Joanne, Zwarenstein, Merrick, Bhattacharyya, Onil, \& Reeves, Scott (2009). Improving the clarity of the interprofessional field: Implications for research and continuing interprofessional education. Journal of Continuing Education in the Health Professions, 29(3), 151-156.

36. Lemieux-Charles, Louise, \& McGuire, Wendy L. (2006). What do we know about health care team effectiveness? A review of the literature. Medical Care Research and Review, 63(3), 263-300.

37. Department of Health. (2014). Primary health networks. URL: http://www.health.gov.au/internet /main/publishing.nsf/content/primary_health_networks [November 12, 2015].

38. Department of Health and Human Services. (2014). One state, one health system, better outcomes. URL: http://www.dhhs.tas.gov.au/onehealthsystem [November 12, 2015].

39. Stone, J. (2008). Interprofessional working, distance no barrier. CAIPE Bulletin, April, 15-16.

40. Department of Health and Human Services. (n.d.). Services. URL: http://www.dhhs.tas.gov.au/ [November 12, 2015].

41. Tasmania Medicare Local. (2014). 2013 Census of Tasmanian general practices. Hobart, AU: Tasmania Medicare Local.

42. Lawn, Sharon, Lloyd, Andrea, King, Alison, Sweet, Linda, \& Gum, Lyn (2014). Integration of primary health services: Being put together does not mean they will work together. BMC Research Notes, 7, 66.

43. Xyrichis, Andreas, \& Lowton, Karen (2008). What fosters or prevents interprofessional teamworking in primary and community care? A literature review. International Journal of Nursing Studies, $45,140-153$.

44. Schadewaldt, Verena, McInnes, Elizabeth, Hiller, Janet E., \& Gardner, Anne (2013). Views and experiences of nurse practitioners and medical practitioners with collaborative practice in primary health care - an integrative review. BMC Family Practice, 14, 132.

45. Mitchell, Geoffrey K., Tieman, Jennifer J., \& Shelby-James, Tania M. (2008). Multidisciplinary care planning and teamwork in primary care. Medical Journal of Australia, 188(8), S61-S64.

Journal of Research in Interprofessional Practice and Education

Vol. 6.1

June 2016
46. Barnett, Stephen, Jones, Sandra C., Bennett, Sue, Iverson, Don, \& Bonney, Andrew (2012). General practice training and virtual communities of practice - a review of the literature. BMC Family Practice, 13, 87.

47. Yee, Melissa, Simpson-Young, Virginia, Paton, Rebecca, \& Zuo, Yeqin (2014). How do GPs want to learn in the digital era? Australian Family Physician, 43(6), 399-402. 


\section{JRIPE}

Delphi Technique in Interprofessional Training

Bentley, Kerr, \& Powell

\section{Journal of Research in Interprofessional Practice and Education}

48. Wong, Geoff, Greenhalgh, Trisha, \& Pawson, Ray (2010). Internet-based medical education: A realist review of what works, for whom and in what circumstances. BMC Medical Education, 10, 12.

49. Rowe, Michael, Frantz, Jose, \& Bozalek, Vivienne (2012). The role of blended learning in the clinical education of healthcare students: A systematic review. Medical Teacher, 34(4), e216-e221.

50. McKenna, H. (1994). The Delphi technique: A worthwhile research approach for nursing? Journal of Advanced Nursing, 19, 1221-1225.

51. Boulkedid, Rym, Abdoul, Hendy, Loustau, Marine, Sibony, Olivier, \& Alberti, Corinne (2011). Using and reporting the Delphi method for selecting healthcare quality indicators: A systematic review. Plos One, 6(6), e20476.

52. Syed, Ahmed, Hjarnø, Lulu, \& Aro, Arja R. (2009). The Delphi technique in developing international health policies: Experience from the SARSControl project. The Internet Journal of Health, 8, 2.

53. Dawes, John G. (2008). Do data characteristics change according to the number of scale points used? An experiment using 5 point, 7 point and 10 point scales. International Journal of Market Research, 51, 1.

54. Willcox, Sharon, Lewis, Geraint, \& Burgers, Jako (2011). Strengthening primary care: Recent reforms and achievements in Australia, England, and the Netherlands. Issue Brief (Commonwealth Fund), 27, 1-19.

55. Boeckxstaens, Pauline, \& De Graaf, Pim (2011). Primary care and care for older persons: Position paper of the European Forum for Primary Care. Quality in Primary Care, 19(6), 369-389.

56. Harris, Mark F., Proudfoot, Judy G., Jayasinghe, Upali W., Holton, Christine H., Powell Davies, Gawaine P., Amoroso, Cheryl L., Bubner, Tanya K., \& Bielby, Justin J. (2007). Job satisfaction of staff and the team environment in Australian general practice. Medical Journal of Australia, 186(11), 570 .

57. Drummond, Neil, Abbott, Karen, Williamson, Tyler, \& Somji, Behnaz (2012). Interprofessional primary care in academic family medicine clinics: Implications for education and training. Canadian Family Physician, 58(8), e450-e458.

58. D’Amour, Danielle, Ferrada-Videla, Marcela, San Martin-Rodriguez, Leticia, \& Beaulieu, MarieDominique. (2005). The conceptual basis for interprofessional collaboration: Core concepts and theoretical frameworks. Journal of Interprofessional Care, 19(S1), 116-131. 


\section{Appendix 1}

\section{Rapid review papers}

\begin{tabular}{|c|c|c|c|c|}
\hline Area & Country & Type & Reference & Conclusions from abstract \\
\hline $\begin{array}{l}\text { Case-based } \\
\text { learning }\end{array}$ & Australia & $\begin{array}{l}\text { Systematic } \\
\text { review }\end{array}$ & $\begin{array}{l}\text { Thistlethwaite JE, Davies D, Ekeocha S, Kidd JM, MacDougall C, } \\
\text { Matthews P, Purkis J, Clay D. The effectiveness of case-based } \\
\text { learning in health professional education. A BEME systematic } \\
\text { review: BEME Guide No. 23. Medical Teacher. 2012;34(6):e421-444. }\end{array}$ & $\begin{array}{l}\text { The empirical data taken as a whole are inconclusive as to the effects on learning } \\
\text { compared with other types of activity. Teachers enjoy CBL, partly because it engages, } \\
\text { and is perceived to motivate, students. CBL seems to foster learning in small groups } \\
\text { though whether this is the case delivery or the group learning effect is unclear. }\end{array}$ \\
\hline Clinical education & $\begin{array}{l}\text { United } \\
\text { Kingdom }\end{array}$ & Review & $\begin{array}{l}\text { Pollard C, Ellis L, Stringer E, Cockayne D. Clinical education: a } \\
\text { review of the literature. Nurse Education in Practice. 2007; } \\
\text { 7(5):315-322. }\end{array}$ & $\begin{array}{l}\text { Clinical educators have reported to have been introduced to meet the professional } \\
\text { educational needs of the workforce but there is little empirical or theoretical evidence } \\
\text { to support or refute this. }\end{array}$ \\
\hline $\begin{array}{l}\text { Clinical } \\
\text { supervision } \\
\text { policy - allied } \\
\text { health }\end{array}$ & Australia & Review & $\begin{array}{l}\text { Fitzpatrick S, Smith M, Wilding C. Quality allied health clinical } \\
\text { supervision policy in Australia: a literature review. Australian } \\
\text { Health Review. 2012; 6(4):461-465. }\end{array}$ & $\begin{array}{l}\text { A clear understanding of clinical supervision and how to implement it in allied health } \\
\text { is currently lacking ... gaining an understanding of what high quality clinical } \\
\text { supervision is and how it is best put into practice ... will form the first step in } \\
\text { developing an understandable and useful universal supervision policy for all allied } \\
\text { health professionals. }\end{array}$ \\
\hline Collaboration & Canada & Review & $\begin{array}{l}\text { San Martín-Rodríguez L, Beaulieu MD, D'Amour D, Ferrada- } \\
\text { Videla M. The determinants of successful collaboration: a } \\
\text { review of theoretical and empirical studies. Journal of } \\
\text { Interprofessional Care. 2005; } 19 \text { Suppl 1:132-147. }\end{array}$ & $\begin{array}{l}\text { Very little of the empirical work has dealt with determinants of interprofessional } \\
\text { collaboration in health, particularly its organizational and systemic determinants. } \\
\text { Furthermore, a systemic approach should be adopted in evaluative research on the } \\
\text { determinants of effective collaborative practice. }\end{array}$ \\
\hline $\begin{array}{l}\text { Collaborative } \\
\text { practice }\end{array}$ & USA & $\begin{array}{l}\text { Review and } \\
\text { case study }\end{array}$ & $\begin{array}{l}\text { Chambers R, Tullys T, Mayer K, Wigand D. Regional collaborative } \\
\text { practice in psychiatric rehabilitation and recovery: a best } \\
\text { practice model. Journal of Social Work in Disability \& } \\
\text { Rehabilitation. 2008; 7(3-4):187-231. }\end{array}$ & $\begin{array}{l}\text { This article reviews the current literature related to the elements that make } \\
\text { collaboration within large systems successful. The Greater Bay Area Mental Health and } \\
\text { Education Workforce Collaborative is highlighted as a California best practices model } \\
\text { for regional partnership development and implementation. Also included is a second } \\
\text { case example in one of the Greater Bay Area Collaborative member counties. }\end{array}$ \\
\hline
\end{tabular}


Appendix 1 (cont.)

\begin{tabular}{|c|c|c|c|c|}
\hline Area & Country & Type & Reference & Conclusions from abstract \\
\hline $\begin{array}{l}\text { Communities of } \\
\text { practice }\end{array}$ & Australia & $\begin{array}{l}\text { Systematic } \\
\text { review }\end{array}$ & $\begin{array}{l}\text { Ranmuthugala G, Plumb JJ, Cunningham FC, Georgiou A, } \\
\text { Westbrook JI, Braithwaite J. How and why are communities of } \\
\text { practice established in the healthcare sector? A systematic review } \\
\text { of the literature. BMC Health Services Research. 2011; 11:273. }\end{array}$ & $\begin{array}{l}\text { Cultivating CoPs to improve healthcare performance requires a greater understanding } \\
\text { of how to establish and support CoPs to maximise their potential to improve } \\
\text { healthcare. }\end{array}$ \\
\hline $\begin{array}{l}\text { Communities of } \\
\text { practice }\end{array}$ & Australia & Review & $\begin{array}{l}\text { Barnett S, Jones SC, Bennett S, Iverson D, Bonney A. General } \\
\text { practice training and virtual communities of practice - a review } \\
\text { of the literature. BMC Family Practice. 2012; 13:87. }\end{array}$ & $\begin{array}{l}\text { Virtual communities of practice (VCoPs) in business have been shown to be effective } \\
\text { in improving knowledge sharing, thus reducing professional and structural isolation. } \\
\text {... Further research is needed to clarify whether this framework is an effective } \\
\text { method of health VCoP development and if these VCoPs overcome isolation and thus } \\
\text { improve rural retention of General Practice registrars. }\end{array}$ \\
\hline $\begin{array}{l}\text { Interdisciplinary } \\
\text { education and } \\
\text { teamwork }\end{array}$ & Canada & Review & $\begin{array}{l}\text { Hall P, Weaver L. Interdisciplinary education and teamwork: a } \\
\text { long and winding road. Medical Education. 2001; 35(9):867- } \\
875 .\end{array}$ & $\begin{array}{l}\text { Much of the literature pertained to programme evaluations of academic activities, } \\
\text { and did not compare interdisciplinary education with traditional methods. Many } \\
\text { questions about when to educate, who to educate and how to educate remain } \\
\text { unanswered and open to future research. }\end{array}$ \\
\hline Integrated care & $\begin{array}{l}\text { United } \\
\text { Kingdom }\end{array}$ & Review & $\begin{array}{l}\text { Howarth M, Holland K, Grant MJ. Education needs for } \\
\text { integrated care: a literature review. Journal of Advanced } \\
\text { Nursing. 2006; } 56(2): 144-156 .\end{array}$ & $\begin{array}{l}\text { Six themes were identified which indicate essential elements needed for integrated } \\
\text { care: need for effective communication between professional groups within teams } \\
\text { and an emphasis on role awareness; education about the importance of partnership } \\
\text { working and the need for professionals to develop skills in relation to practice } \\
\text { development and leadership through professional and personal development. }\end{array}$ \\
\hline $\begin{array}{l}\text { Internet-based } \\
\text { learning }\end{array}$ & USA & $\begin{array}{l}\text { Systematic } \\
\text { review }\end{array}$ & $\begin{array}{l}\text { Cook DA, Levinson AJ, Garside S, Dupras DM, Erwin PJ, Montori } \\
\text { VM. Internet-based learning in the health professions: a meta- } \\
\text { analysis. JAMA. 2008; 300(10):1181-1196. }\end{array}$ & $\begin{array}{l}\text { Internet-based learning is associated with large positive effects compared with no } \\
\text { intervention. In contrast, effects compared with non-Internet instructional methods are } \\
\text { heterogeneous and generally small, suggesting effectiveness similar to traditional } \\
\text { methods. Future research should directly compare different Internet-based interventions. }\end{array}$ \\
\hline
\end{tabular}




\section{Appendix 1 (cont.)}

\begin{tabular}{|c|c|c|c|c|}
\hline Area & Country & Type & Reference & Conclusions from abstract \\
\hline $\begin{array}{l}\text { Internet-based } \\
\text { medical } \\
\text { education }\end{array}$ & $\begin{array}{l}\text { United } \\
\text { Kingdom }\end{array}$ & Review & $\begin{array}{l}\text { Wong G, Greenhalgh T, Pawson R. Internet-based medical } \\
\text { education: a realist review of what works, for whom and in } \\
\text { what circumstances. BMC Medical Education. 2010; 10:12. }\end{array}$ & $\begin{array}{l}\text { Learners were more likely to accept a course if it offered a perceived advantage over } \\
\text { available non-Internet alternatives, was easy to use technically, and compatible with } \\
\text { their values and norms. 'Interactivity' led to effective learning only if learners were } \\
\text { able to enter into a dialogue - with a tutor, fellow students or virtual tutorials - and } \\
\text { gain formative feedback.... When designing or choosing an Internet-based course, } \\
\text { attention must be given to the fit between its technical attributes and learners' needs } \\
\text { and priorities; and to ways of providing meaningful interaction. }\end{array}$ \\
\hline $\begin{array}{l}\text { Interprofessional } \\
\text { clinical education }\end{array}$ & Australia & $\begin{array}{l}\text { Systematic } \\
\text { review }\end{array}$ & $\begin{array}{l}\text { Davidson M, Smith RA, Dodd KJ, Smith JS, O'Loughlan MJ. } \\
\text { Interprofessional pre-qualification clinical education: a systematic } \\
\text { review. Australian Health Review. 2008; 32(1):111-120. }\end{array}$ & $\begin{array}{l}\text { Detailed planning, stakeholder enthusiasm and commitment appear to be essential } \\
\text { to the success of IPCE. The literature provides guiding principles for establishing a } \\
\text { program; however, there is limited evidence to support a particular approach. }\end{array}$ \\
\hline $\begin{array}{l}\text { Interprofessional } \\
\text { education }\end{array}$ & Australia & Review & $\begin{array}{l}\text { Lapkin S, Levett-Jones T, Gilligan C. A systematic review of the } \\
\text { effectiveness of interprofessional education in health professional } \\
\text { programs. Nurse Education Today. 2013;33(2):90-102. }\end{array}$ & $\begin{array}{l}\text { Student's attitudes and perceptions towards interprofessional collaboration and clinical } \\
\text { decision-making can be potentially enhanced through interprofessional education. } \\
\text { However, the evidence for using interprofessional education to teach communication } \\
\text { skills and clinical skills is inconclusive and requires further investigation. }\end{array}$ \\
\hline $\begin{array}{l}\text { Interprofessional } \\
\text { education }\end{array}$ & $\begin{array}{l}\text { United } \\
\text { Kingdom/ } \\
\text { Australia }\end{array}$ & Review & $\begin{array}{l}\text { Thistlethwaite J, Moran M. Learning outcomes for } \\
\text { interprofessional education (IPE): Literature review and synthesis. } \\
\text { Journal of Interprofessional Care. 2010; 24(5):503-513 }\end{array}$ & $\begin{array}{l}\text { There is a variety in the way learning outcomes are presented but there are many } \\
\text { similarities between specific outcomes and/or objectives. Papers describing } \\
\text { educational interventions do not always include specific outcomes or objectives. }\end{array}$ \\
\hline $\begin{array}{l}\text { Interprofessional } \\
\text { education }\end{array}$ & USA & Review & $\begin{array}{l}\text { Lavin MA, Ruebling I, Banks R, Block L, Counte M, Furman G, } \\
\text { Miller P, Reese C, Viehmann V, Holt J. Interdisciplinary health } \\
\text { professional education: a historical review. Advances in Health } \\
\text { Science Education Theory \& Practice. 2001; 6(1):25-47. }\end{array}$ & $\begin{array}{l}\text { A historical review to examine the advances made, nationally and internationally, in } \\
\text { interdisciplinary health professional education since the mid-1960s: models (defined } \\
\text { the conceptual field, described curriculum and program development, or provided a } \\
\text { framework for evaluation), courses (focusing on objectives, content areas, or } \\
\text { innovative methods), communication/group process issues (from which guidelines } \\
\text { were abstracted), and international perspectives (recognition that interdisciplinary } \\
\text { health professional education, practice, and research is a global movement). }\end{array}$ \\
\hline
\end{tabular}




\section{Appendix 1 (cont.)}

\begin{tabular}{|c|c|c|c|c|}
\hline Area & Country & Type & Reference & Conclusions from abstract \\
\hline $\begin{array}{l}\text { Interprofessional } \\
\text { education }\end{array}$ & $\begin{array}{l}\text { United } \\
\text { Kingdom }\end{array}$ & $\begin{array}{l}\text { Systematic } \\
\text { review }\end{array}$ & $\begin{array}{l}\text { Hammick M, Freeth D, Koppel I, Reeves S, Barr H. A best } \\
\text { evidence systematic review of interprofessional education: } \\
\text { BEME Guide no. 9. Medical Teacher. 2007; 29:735-751. }\end{array}$ & $\begin{array}{l}\text { Staff development is a key influence on the effectiveness of IPE for learners who all } \\
\text { have unique values about themselves and others. Authenticity and customization of } \\
\text { IPE are important mechanisms for positive outcomes of IPE. Interprofessional } \\
\text { education is generally well received, enabling knowledge and skills necessary for } \\
\text { collaborative working to be learnt; it is less able to positively influence attitudes and } \\
\text { perceptions towards others in the service delivery team. In the context of quality } \\
\text { improvement initiatives interprofessional education is frequently used as a } \\
\text { mechanism to enhance the development of practice and improvement of services. }\end{array}$ \\
\hline $\begin{array}{l}\text { Interprofessional } \\
\text { education }\end{array}$ & Canada & $\begin{array}{l}\text { Systematic } \\
\text { review }\end{array}$ & $\begin{array}{l}\text { Reeves S., Zwarenstein M, Goldman J, Barr H, Freeth D, Koppel I, } \\
\text { Hammick M. The effectiveness of interprofessional education: } \\
\text { Key findings from a new systematic review. Journal of } \\
\text { Interprofessional Care. 2010; 24(3): 230-241. }\end{array}$ & $\begin{array}{l}\text { Four out of the six studies reported a range of positive outcomes providing further } \\
\text { incentive to continue to understand, in more comprehensive terms, the effects of IPE. } \\
\text { The findings from this review can contribute to the accumulating evidence that has } \\
\text { been generated by the growing amount of research and systematic reviews } \\
\text { completed in recent years. The findings from this review point to the need to continue } \\
\text { to strengthen the quality of studies employing both quantitative and qualitative } \\
\text { methods to ensure they can provide comprehensive insights into the effects of IPE. }\end{array}$ \\
\hline $\begin{array}{l}\text { Interprofessional } \\
\text { education }\end{array}$ & Canada & $\begin{array}{l}\text { Systematic } \\
\text { review }\end{array}$ & $\begin{array}{l}\text { Zwarenstein M, Goldman J, Reeves S. Interprofessional } \\
\text { collaboration: effects of practice-based interventions on } \\
\text { professional practice and healthcare outcomes. Cochrane } \\
\text { Database of Systematic Reviews. 2009; Issue 3. Art. No.: } \\
\text { CD000072. D0I: 10.1002/14651858.CD000072.pub2. }\end{array}$ & $\begin{array}{l}\text { Monthly multidisciplinary team meetings improved prescribing of psychotropic drugs } \\
\text { in nursing homes. Videoconferencing compared to audioconferencing } \\
\text { multidisciplinary case conferences showed mixed results; there was a decreased } \\
\text { number of case conferences per patient and shorter length of treatment, but no } \\
\text { differences in occasions of service or the length of the conference. There was also no } \\
\text { difference between the groups in the number of communications between health } \\
\text { professionals recorded in the notes. Multidisciplinary meetings with an external } \\
\text { facilitator, who used strategies to encourage collaborative working, was associated } \\
\text { with increased audit activity and reported improvements to care. }\end{array}$ \\
\hline
\end{tabular}




\section{Appendix 1 (cont.)}

\begin{tabular}{|c|c|c|c|c|}
\hline Area & Country & Type & Reference & Conclusions from abstract \\
\hline $\begin{array}{l}\text { Interprofessional } \\
\text { education }\end{array}$ & Canada & $\begin{array}{l}\text { Systematic } \\
\text { review }\end{array}$ & $\begin{array}{l}\text { Reeves S, Zwarenstein M, Goldman J, Barr H, Freeth D, } \\
\text { Hammick M, Koppel I. Interprofessional education: } \\
\text { effects on professional practice and health care } \\
\text { outcomes. Cochrane Database of Systematic Reviews. } \\
\text { 2008; Issue 1. Art. No.: } \\
\text { CD002213. D0I: 10.1002/14651858.CD002213.pub2. }\end{array}$ & $\begin{array}{l}\text { Although these studies reported some positive outcomes, due to the small number of } \\
\text { studies, the heterogeneity of interventions, and the methodological limitations, it is not } \\
\text { possible to draw generalisable inferences about the key elements of IPE and its } \\
\text { effectiveness. More rigorous IPE studies are needed to provide better evidence of the impact } \\
\text { of IPE on professional practice and healthcare outcomes. These studies should also include } \\
\text { data collection strategies that provide insight into how IPE affects changes in health care } \\
\text { processes and patient outcomes. }\end{array}$ \\
\hline $\begin{array}{l}\text { Interprofessional } \\
\text { education }\end{array}$ & Canada & Review & $\begin{array}{l}\text { D'Amour D, Ferrada-Videla M, San Martin Rodriguez L, } \\
\text { Beaulieu M-D. The conceptual basis for interprofessional } \\
\text { collaboration: Core concepts and theoretical frameworks. } \\
\text { Journal of Interprofessional Care. 2005; Supplement 1: } \\
\text { 116-131. }\end{array}$ & $\begin{array}{l}\text { Our results demonstrate that: (1) the concept of collaboration is commonly defined through } \\
\text { five underlying concepts: sharing, partnership, power, interdependency and process; (2) the } \\
\text { most complete models of collaboration seem to be those based on a strong theoretical } \\
\text { background, either in organizational theory or in organizational sociology and on empirical } \\
\text { data; (3) there is a significant amount of diversity in the way the various authors } \\
\text { conceptualized collaboration and in the factors influencing collaboration; (4) these } \\
\text { frameworks do not establish clear links between the elements in the models and the } \\
\text { outputs; and (5) the literature does not provide a serious attempt to determine how patients } \\
\text { could be integrated into the health care team, despite the fact that patients are recognized } \\
\text { as the ultimate justification for providing collaborative care. }\end{array}$ \\
\hline $\begin{array}{l}\text { Interprofessional } \\
\text { education and } \\
\text { collaborative } \\
\text { practice }\end{array}$ & Canada & Review & $\begin{array}{l}\text { Ginsburg L, Tregunno D. New approaches to } \\
\text { interprofessional education and collaborative practice: } \\
\text { lessons from the organizational change literature. } \\
\text { Journal of Interprofessional Care. 2005; } 19 \text { Suppl 1:177- } \\
\text { 187. }\end{array}$ & $\begin{array}{l}\text { A variety of issues from the organizational change literature that are especially relevant to } \\
\text { the implementation of initiatives in interprofessional education (IPE) for collaborative } \\
\text { practice (CP). At the level of the individual: the existence of strong professional cultures and } \\
\text { the need to motivate change. At the level of the organization, context and leadership for IPE } \\
\text { and }(P \text { are relevant. At the system level, a discussion of incremental versus radical forces for } \\
\text { change is particularly germane. Concludes with a set of key recommendations suggested for } \\
\text { reducing the incidence of implementation failure. }\end{array}$ \\
\hline
\end{tabular}


Appendix 1 (cont.)

\begin{tabular}{|c|c|c|c|c|}
\hline Area & Country & Type & Reference & Conclusions from abstract \\
\hline $\begin{array}{l}\text { Interprofessional } \\
\text { learning }\end{array}$ & $\begin{array}{l}\text { United } \\
\text { Kingdom }\end{array}$ & Review & $\begin{array}{l}\text { Mattick K, Bligh J. Interprofessional learning involving } \\
\text { medical students or doctors. Medical Education. 2003; } \\
\text { 37(11):1008-1111. }\end{array}$ & $\begin{array}{l}\text { More and better quality research is required as more resources become available to } \\
\text { academic and health care organisations for interprofessional learning. }\end{array}$ \\
\hline $\begin{array}{l}\text { Interprofessional } \\
\text { simulation-based } \\
\text { education }\end{array}$ & $\begin{array}{l}\text { United } \\
\text { Kingdom }\end{array}$ & Review & $\begin{array}{l}\text { Gough S, Hellaby M, Jones N, Mackinnon R. A review of } \\
\text { undergraduate interprofessional simulation-based } \\
\text { education (IPSE). Collegian. 2012; 19(3):153-170. }\end{array}$ & $\begin{array}{l}\text { Key IPSE drivers included capacity planning, preparedness for disaster management and } \\
\text { improving patient care through the evaluation of teambuilding, teamwork skills or } \\
\text { communicating within inter-disciplinary teams. }\end{array}$ \\
\hline $\begin{array}{l}\text { Interprofessional } \\
\text { teamworking }\end{array}$ & $\begin{array}{l}\text { United } \\
\text { Kingdom }\end{array}$ & Review & $\begin{array}{l}\text { Xyrichis A, Lowton K. What fosters or prevents } \\
\text { interprofessional teamworking in primary and } \\
\text { community care? A literature review. International } \\
\text { Journal of Nursing Studies. 2008; } 45(1): 140-153 .\end{array}$ & $\begin{array}{l}\text { Two main themes emerged that had an impact on interprofessional teamworking: team } \\
\text { structure and team processes. Within these two themes, six categories were identified: team } \\
\text { premises; team size and composition; organisational support; team meetings; clear goals } \\
\text { and objectives; and audit. }\end{array}$ \\
\hline $\begin{array}{l}\text { Peer teaching } \\
\text { and learning }\end{array}$ & Australia & $\begin{array}{l}\text { Systematic } \\
\text { review }\end{array}$ & $\begin{array}{l}\text { Secomb J. A systematic review of peer teaching and } \\
\text { learning in clinical education. Journal of Clinical Nursing. } \\
\text { 2008; 17(6):703-716. }\end{array}$ & $\begin{array}{l}\text { Mostly positive outcomes on the effectiveness of peer teaching and learning: can increase } \\
\text { student's confidence in clinical practice and improve learning in the psychomotor and } \\
\text { cognitive domains. Negative aspects: poor student learning if personalities or learning styles } \\
\text { are not compatible and students spending less individualized time with the clinical } \\
\text { instructor. ... Preclinical education of students increases student educational outcomes } \\
\text { from peer teaching and learning. Strategies are required prior to clinical placement to } \\
\text { accommodate incompatible students or poor student learning. ... Peer teaching and } \\
\text { learning can increase clinical placement opportunities for undergraduate health students, } \\
\text { assist clinical staff with workload pressures and increase clinician time with clients, while } \\
\text { further developing students' knowledge, skills and attitudes. }\end{array}$ \\
\hline
\end{tabular}




\section{Appendix 1 (cont.)}

\begin{tabular}{|c|c|c|c|c|}
\hline Area & Country & Type & Reference & Conclusions from abstract \\
\hline $\begin{array}{l}\text { Post-graduate } \\
\text { training }\end{array}$ & Belgium & $\begin{array}{l}\text { Systematic } \\
\text { review }\end{array}$ & $\begin{array}{l}\text { Damen A, Remmen R, Wens J, Paulus D. Evidence based } \\
\text { post graduate training. A systematic review of reviews } \\
\text { based on the WFME quality framework. BMC Medical } \\
\text { Education. 2011; } 11: 80 \text {. }\end{array}$ & $\begin{array}{l}\text { Indicators used for quality assessment purposes of post graduate training should be based } \\
\text { on this evidence but further research is needed for some areas in particular to assess the } \\
\text { quality of the training process. }\end{array}$ \\
\hline $\begin{array}{l}\text { Practice-based } \\
\text { small group } \\
\text { learning } \\
\text { programs }\end{array}$ & Canada & $\begin{array}{l}\text { Systematic } \\
\text { review }\end{array}$ & $\begin{array}{l}\text { Zaher E, Ratnapalan S. Practice-based small group } \\
\text { learning programs: systematic review. Canadian Family } \\
\text { Physician. 2012; 58(6):637-642, e310-316. }\end{array}$ & $\begin{array}{l}\text { Current evidence suggests that PBSGL is a promising method of continuing professional } \\
\text { development for FPs. Such programs can be adapted according to learning needs. Future } \\
\text { studies that focus on the changes in practice effected by PBSGL will strengthen the evidence } \\
\text { for this form of learning and motivate physicians and institutions to adopt it. }\end{array}$ \\
\hline Preceptors & Australia & $\begin{array}{l}\text { Systematic } \\
\text { review }\end{array}$ & $\begin{array}{l}\text { Stagg P, Prideaux D, Greenhill J, Sweet L. Are medical } \\
\text { students influenced by preceptors in making career } \\
\text { choices, and if so how? A systematic review. Rural \& } \\
\text { Remote Health. 2012; 12:1832. }\end{array}$ & $\begin{array}{l}\text { Through a mix of short- and long-term preceptorships, clerkships and rotations, medical } \\
\text { students are exposed to a wider range of preceptors, mentors and role models than has } \\
\text { traditionally been the case. ... Preceptors who are judged (by students) as high quality } \\
\text { teachers have the greatest influence on student career choice by up to four-fold. When } \\
\text { students judged a preceptor as being a negative role model, a poor teacher or lacking } \\
\text { discipline specific knowledge they will turn away from that field. The positive influence of } \\
\text { relationships between preceptors and students on career choice is strongest where there is } \\
\text { continuity of preceptors, continuity of care, and continuity of patient interactions. The longer } \\
\text { the duration of the preceptorship the greater the influence on student career choice, } \\
\text { particularly in primary cares environments. }\end{array}$ \\
\hline Preceptors & Australia & Review & $\begin{array}{l}\text { Walters L, Worley P, Prideaux D, Rolfe H, Keaney C. The } \\
\text { impact of medical students on rural general practitioner } \\
\text { preceptors. Education for Health. 2005; 18(3):338-355. }\end{array}$ & $\begin{array}{l}\text { Impacts on rural GPs were categorized into six domains: personal; time; patient care; } \\
\text { professional relationships and professional development; business and infrastructure; and } \\
\text { recognition and remuneration. }\end{array}$ \\
\hline
\end{tabular}




\section{Appendix 1 (cont.)}

\begin{tabular}{|c|c|c|c|c|}
\hline Area & Country & Type & Reference & Conclusions from abstract \\
\hline Rural placements & USA & Review & $\begin{array}{l}\text { Barrett FA, Lipsky MS, Lutfiyya MN. The impact of rural } \\
\text { training experiences on medical students: a critical } \\
\text { review. Academic Medicine. 2011; 86(2):259-263. }\end{array}$ & $\begin{array}{l}\text { This review shows that placement in rural settings is a positive learning experience that } \\
\text { students and preceptors value. It is not clear whether rotations reinforce pre-existing } \\
\text { interest or have the ability to motivate previously uninterested students to consider careers } \\
\text { in primary care or rural medicine. }\end{array}$ \\
\hline $\begin{array}{l}\text { Teaching } \\
\text { effectiveness in } \\
\text { medical } \\
\text { education }\end{array}$ & Canada & $\begin{array}{l}\text { Systematic } \\
\text { review }\end{array}$ & $\begin{array}{l}\text { Steinert Y, Mann K, Centeno A, Dolmans D, Spencer J, } \\
\text { Gelula M, Prideaux D. A systematic review of faculty } \\
\text { development initiatives designed to improve teaching } \\
\text { effectiveness in medical education: BEME Guide No. } 8 . \\
\text { Medical Teacher. 2006; 28(6):497-526. }\end{array}$ & $\begin{array}{l}\text { Key features of effective faculty development contributing to effectiveness included the use } \\
\text { of experiential learning, provision of feedback, effective peer and colleague relationships, } \\
\text { well-designed interventions following principles of teaching and learning, and the use of a } \\
\text { diversity of educational methods within single interventions. }\end{array}$ \\
\hline $\begin{array}{l}\text { Undergraduate } \\
\text { community- } \\
\text { based education }\end{array}$ & Pakistan & $\begin{array}{l}\text { Systematic } \\
\text { review }\end{array}$ & $\begin{array}{l}\text { Ladhani Z, Scherpbier AJ, Stevens FC. Competencies for } \\
\text { undergraduate community-based education for the } \\
\text { health professions--a systematic review. Medical Teacher. } \\
\text { 2012; 34(9):733-743. }\end{array}$ & $\begin{array}{l}\text { Competencies identified under six themes: Public Health; Cultural Competence; Leadership } \\
\text { and Management; Community Development; Research; and Generic Competencies. ... The } \\
\text { literature on CBE competencies is limited in number and in its geographical span as most of } \\
\text { the studies found was from developed countries. }\end{array}$ \\
\hline $\begin{array}{l}\text { Undergraduate } \\
\text { student learning }\end{array}$ & $\begin{array}{l}\text { United } \\
\text { Kingdom }\end{array}$ & $\begin{array}{l}\text { Systematic } \\
\text { review }\end{array}$ & $\begin{array}{l}\text { Buckley S, Coleman J, Davison I, Khan KS, Zamora J, } \\
\text { Malick S, Morley D, Pollard D, Ashcroft T, Popovic C, } \\
\text { Sayers J. The educational effects of portfolios on } \\
\text { undergraduate student learning: a Best Evidence } \\
\text { Medical Education (BEME) systematic review. BEME } \\
\text { Guide No. 11. Medical Teacher. 2009; 31(4):282-98. }\end{array}$ & $\begin{array}{l}\text { Whilst portfolios encourage students to engage in reflection, the quality of those reflections } \\
\text { cannot be assumed and that the time commitment required for portfolio completion may } \\
\text { detract from other learning or deter students from engaging with the process unless } \\
\text { required to do so by the demands of assessment. }\end{array}$ \\
\hline
\end{tabular}




\section{Appendix 1 (cont.)}

\section{Big picture decisions - the why?}

The literature review reveals that very little of the empirical work has dealt with determinants of interprofessional collaboration in health, particularly its organizational and systemic determinants (San Martinez et al, 2005).

Interprofessional education is generally well received, enabling knowledge and skills necessary for collaborative working to be learnt; it is less able to positively influence attitudes and perceptions towards others in the service delivery team (Hammick et al, 2007).

Detailed planning, stakeholder enthusiasm and commitment appear to be essential to the success of IPCE. The literature provides guiding principles for establishing a program; however, there is limited evidence to support a particular approach (Davidson et al, 2008).

\section{Defining and understanding capabilities - the what?}

The six broad themes of the outcomes are: teamwork; roles and responsibilities; communication; learning and reflection; the patient/client; ethics and attitudes (Thistlethwaite \& Moran, 2010).

\section{Teaching and learning - the how?}

\section{Case based learning}

Teachers enjoy CBL, partly because it engages, and is perceived to motivate, students. However, the empirical data taken as a whole are inconclusive as to the effects on learning compared with other types of activity. CBL seems to foster learning in small groups though whether this is the case delivery or the group learning effect is unclear (Thistlethwaite et al. 2012).

\section{Communities of practice}

Cultivating communities of practice to improve healthcare performance requires a greater understanding of how to establish and support communities of practice to maximise their potential to improve healthcare (Ranmuthugala et al, 2011). Whether virtual communities of practice overcome isolation and thus improve rural retention of General Practice registrars requires further research (Barnett et al, 2012). 


\section{Appendix 1 (cont.)}

\section{Internet-based learning}

Learners are more likely to accept an Internet-based course if it offered a perceived advantage over available non-Internet alternatives, was easy to use technically, and compatible with their values and norms. However, effects compared with non-Internet instructional methods are heterogeneous and generally small, suggesting effectiveness similar to traditional methods. Future research should directly compare different Internet-based interventions (Wong et al, 2010).

\section{Peer teaching and learning}

Peer teaching and learning can increase students' confidence in clinical practice. Preclinical education of students increases student educational outcomes from peer teaching and learning. Peer teaching and learning can increase clinical placement opportunities for undergraduate health students, assist clinical staff with workload pressures and increase clinician time with clients, while further developing students' knowledge, skills and attitudes (Secomb 2008).

\section{Practice-based small group learning programs}

Practice-based small group learning is a promising method of continuing professional development for general practices. Future studies that focus on the changes in practice effected by practice-based small group learning will strengthen the evidence for this form of learning and motivate physicians and institutions to adopt it (Zaher \& Ratnapalan 2012).

\section{Simulation-based education}

Interprofessional simulation-based education needs capacity planning, preparedness for disaster management and improving patient care through the evaluation of teambuilding, teamwork skills or communicating within inter-disciplinary teams (Gough et al, 2012).

\section{Organisation - the where?}

Two main themes emerged that had an impact on interprofessional teamworking: team structure and team processes. Within these two themes, six categories were identified: team premises; team size and composition; organisational support; team meetings; clear goals and objectives; and audit (Xyrichis \& Lowton, 2008). 


\section{JRIPE}

Delphi Technique in Interprofessional Training

Bentley, Kerr, \& Powell

\section{Integrated Roadmap to Best Practice Training in Primary Health Care Training in Tasmania}

Round 2

In Round 2 of the project, we are asking you to rate and comment on a series of statements in relation to interprofessional education for collaborative practice.

These statements are informed by the international literature and reflect feedback from the workshops, interviews and survey conducted in Round 1 during April and May.

The statements are grouped under four sections:

1. Big picture (the why?)

2. Capabilities (the what?)

3. Teaching \& Learning (the how?)

4. Organisation (the where?)

There are 33 statements to rate. We ask you to rate each statement and give reasons for your ratings.

\section{Section 1: Big picture decisions - the why?}

This section covers the context of health practice needs in Tasmania.

Q1: Interprofessional training needs to be integrated across primary, secondary and tertiary levels of the health system

\begin{tabular}{|l|l|l|l|l|l|}
\hline $\begin{array}{l}\text { Strongly } \\
\text { disagree }\end{array}$ & Disagree & $\begin{array}{l}\text { Neither agree } \\
\text { nor disagree }\end{array}$ & Agree & $\begin{array}{l}\text { Strongly } \\
\text { agree }\end{array}$ & N/A \\
\hline
\end{tabular}

Your reasons for this rating:

More evidence is needed on the organisational and systemic determinants of interprofessional education for collaborative practice

\begin{tabular}{|l|l|l|l|l|l|}
\hline $\begin{array}{l}\text { Strongly } \\
\text { disagree }\end{array}$ & Disagree & $\begin{array}{l}\text { Neither agree } \\
\text { nor disagree }\end{array}$ & Agree & $\begin{array}{l}\text { Strongly } \\
\text { agree }\end{array}$ & N/A \\
\hline
\end{tabular}

Your reasons for this rating:
Journal of Research in Interprofessional Practice and Education

Vol. 6.1

June 2016 


\section{JRIPE

\section{Appendix 2 (cont.)}

Delphi Technique in Interprofessional Training

Bentley, Kerr, \& Powell
The next 4 statements relate to barriers to interprofessional education for collaborative practice in Tasmania:

The curriculum at the University of Tasmania is too crowded to expand interprofessional education for primary health

\begin{tabular}{|l|l|l|l|l|l|}
\hline $\begin{array}{l}\text { Strongly } \\
\text { disagree }\end{array}$ & Disagree & $\begin{array}{l}\text { Neither agree } \\
\text { nor disagree }\end{array}$ & Agree & $\begin{array}{l}\text { Strongly } \\
\text { agree }\end{array}$ & N/A \\
\hline
\end{tabular}

Your reasons for this rating:

The lack of undergraduate Allied Health education at the University of Tasmania limits opportunities for interprofessional education

\begin{tabular}{|l|l|l|l|l|l|}
\hline $\begin{array}{l}\text { Strongly } \\
\text { disagree }\end{array}$ & Disagree & $\begin{array}{l}\text { Neither agree } \\
\text { nor disagree }\end{array}$ & Agree & $\begin{array}{l}\text { Strongly } \\
\text { agree }\end{array}$ & N/A \\
\hline
\end{tabular}

Your reasons for this rating:

The lack of postgraduate training in Tasmania for some disciplines limits opportunities for interprofessional education

\begin{tabular}{|l|l|l|l|l|l|}
\hline $\begin{array}{l}\text { Strongly } \\
\text { disagree }\end{array}$ & Disagree & $\begin{array}{l}\text { Neither agree } \\
\text { nor disagree }\end{array}$ & Agree & $\begin{array}{l}\text { Strongly } \\
\text { agree }\end{array}$ & N/A \\
\hline
\end{tabular}

Your reasons for this rating:

Existing requirements for continuing professional development limit opportunities for interprofessional training

\begin{tabular}{|l|l|l|l|l|l|}
\hline $\begin{array}{l}\text { Strongly } \\
\text { disagree }\end{array}$ & Disagree & $\begin{array}{l}\text { Neither agree } \\
\text { nor disagree }\end{array}$ & Agree & $\begin{array}{l}\text { Strongly } \\
\text { agree }\end{array}$ & N/A \\
\hline
\end{tabular}

Your reasons for this rating:

Any other comments on this section? 


\section{JRIPE}

Delphi Technique in Interprofessional Training

Bentley, Kerr, \& Powell

Journal of Research in Interprofessional Practice and Education

Vol. 6.1

June 2016
Journal of Research in Interprofessional Practice and Education

\section{Appendix 2 (cont.)}

\section{Section 2: Defining and understanding capabilities - the what?}

This section covers knowledges, competencies, capabilities for interprofessional education and training.

Interprofessional learning outcomes relating to teamwork

Knowledge of, and skills for, teamwork.

\begin{tabular}{|l|l|l|l|l|l|}
\hline $\begin{array}{l}\text { Not at all } \\
\text { important }\end{array}$ & Unimportant & $\begin{array}{l}\text { Neither } \\
\text { unimportant } \\
\text { nor important }\end{array}$ & Important & $\begin{array}{l}\text { Very } \\
\text { important }\end{array}$ & N/A \\
\hline
\end{tabular}

Your reasons for this rating:

Interprofessional learning outcomes related to roles and responsibilities

Knowledge and understanding of the different roles, boundaries, responsibilities and expertise of health professionals

\begin{tabular}{|l|l|l|l|l|l|}
\hline $\begin{array}{l}\text { Not at all } \\
\text { important }\end{array}$ & Unimportant & $\begin{array}{l}\text { Neither } \\
\text { unimportant } \\
\text { nor important }\end{array}$ & Important & $\begin{array}{l}\text { Very } \\
\text { important }\end{array}$ & N/A \\
\hline
\end{tabular}

Your reasons for this rating:

Being able to challenge misconceptions in relations to roles

\begin{tabular}{|l|l|l|l|l|l|}
\hline $\begin{array}{l}\text { Not at all } \\
\text { important }\end{array}$ & Unimportant & $\begin{array}{l}\text { Neither } \\
\text { unimportant } \\
\text { nor important }\end{array}$ & Important & $\begin{array}{l}\text { Very } \\
\text { important }\end{array}$ & N/A \\
\hline
\end{tabular}

Your reasons for this rating:

Interprofessional learning outcomes related to communication

Ability to communicate effectively with other health professional students

\begin{tabular}{|l|l|l|l|l|l|}
\hline $\begin{array}{l}\text { Not at all } \\
\text { important }\end{array}$ & Unimportant & $\begin{array}{l}\text { Neither } \\
\text { unimportant } \\
\text { nor important }\end{array}$ & Important & $\begin{array}{l}\text { Very } \\
\text { important }\end{array}$ & N/A \\
\hline
\end{tabular}

Your reasons for this rating:

Awareness of difference in professionals' language

\begin{tabular}{|l|l|l|l|l|l|}
\hline $\begin{array}{l}\text { Not at all } \\
\text { important }\end{array}$ & Unimportant & $\begin{array}{l}\text { Neither } \\
\text { unimportant } \\
\text { nor important }\end{array}$ & Important & $\begin{array}{l}\text { Very } \\
\text { important }\end{array}$ & N/A \\
\hline
\end{tabular}


Delphi Technique in Interprofessional Training

Bentley, Kerr, \& Powell
Ability to express one's opinions to others involved with care

\begin{tabular}{|l|l|l|l|l|l|}
\hline $\begin{array}{l}\text { Not at all } \\
\text { important }\end{array}$ & Unimportant & $\begin{array}{l}\text { Neither } \\
\text { unimportant } \\
\text { nor important }\end{array}$ & Important & $\begin{array}{l}\text { Very } \\
\text { important }\end{array}$ & N/A \\
\hline
\end{tabular}

Your reasons for this rating:

Interprofessional learning outcomes relating to learning/reflection

Ability to reflect critically on one's own relationship within a team

\begin{tabular}{|l|l|l|l|l|l|}
\hline $\begin{array}{l}\text { Not at all } \\
\text { important }\end{array}$ & Unimportant & $\begin{array}{l}\text { Neither } \\
\text { unimportant } \\
\text { nor important }\end{array}$ & Important & $\begin{array}{l}\text { Very } \\
\text { important }\end{array}$ & N/A \\
\hline
\end{tabular}

Your reasons for this rating:

Ability to transfer interprofessional learning to the clinical setting

\begin{tabular}{|l|l|l|l|l|l|}
\hline $\begin{array}{l}\text { Not at all } \\
\text { important }\end{array}$ & Unimportant & $\begin{array}{l}\text { Neither } \\
\text { unimportant } \\
\text { nor important }\end{array}$ & Important & $\begin{array}{l}\text { Very } \\
\text { important }\end{array}$ & N/A \\
\hline
\end{tabular}

Your reasons for this rating:

Interprofessional learning outcomes relating to the patient/client

The central role of the patient in collaborative care

\begin{tabular}{|l|l|l|l|l|l|}
\hline $\begin{array}{l}\text { Not at all } \\
\text { important }\end{array}$ & Unimportant & $\begin{array}{l}\text { Neither } \\
\text { unimportant } \\
\text { nor important }\end{array}$ & Important & $\begin{array}{l}\text { Very } \\
\text { important }\end{array}$ & N/A \\
\hline
\end{tabular}

Your reasons for this rating:

Understanding of patient safety issues

\begin{tabular}{|l|l|l|l|l|l|}
\hline $\begin{array}{l}\text { Not at all } \\
\text { important }\end{array}$ & Unimportant & $\begin{array}{l}\text { Neither } \\
\text { unimportant } \\
\text { nor important }\end{array}$ & Important & $\begin{array}{l}\text { Very } \\
\text { important }\end{array}$ & N/A \\
\hline
\end{tabular}

Your reasons for this rating:

\section{Interprofessional learning outcomes relating to ethics/attitudes}

Ability to acknowledge views and ideas of other professionals

\begin{tabular}{|l|l|l|l|l|l|}
\hline $\begin{array}{l}\text { Not at all } \\
\text { important }\end{array}$ & Unimportant & $\begin{array}{l}\text { Neither } \\
\text { unimportant } \\
\text { nor important }\end{array}$ & Important & $\begin{array}{l}\text { Very } \\
\text { important }\end{array}$ & N/A \\
\hline
\end{tabular}

Your reasons for this rating: 


\section{JRIPE \\ Journal of Research in Interprofessional Practice and Education}

\section{Appendix 2 (cont.)}

Delphi Technique in Interprofessional Training

Bentley, Kerr, \& Powell

Understanding the ethical issues relating to teamwork

\begin{tabular}{|l|l|l|l|l|l|}
\hline $\begin{array}{l}\text { Not at all } \\
\text { important }\end{array}$ & Unimportant & $\begin{array}{l}\text { Neither } \\
\text { unimportant } \\
\text { nor important }\end{array}$ & Important & $\begin{array}{l}\text { Very } \\
\text { important }\end{array}$ & N/A \\
\hline
\end{tabular}

Your reasons for this rating:

In your opinion, what are the main priority focus areas where interprofessional education for collaborative practice is needed (choose 3 )

- Mental health

- Chronic conditions

- Caring for an ageing population

- Women's and Children's health

- Youth health

- Aboriginal health

- Lesbian, Gay, Bisexual, Transgender, Intersex health

- Refugee health

- $\quad$ Other (please specify)

Any other comments on this section? 


\section{JRIPE}

32

Delphi Technique in Interprofessional Training

Bentley, Kerr, \& Powell

\section{Appendix 2 (cont.)}

\section{Section 3: Teaching and learning - the how?}

This section covers approaches and practices to teaching and learning.

Rate the following modes of interprofessional learning for primary health care professionals

Practice based, small group learning programs

\begin{tabular}{|l|l|l|l|l|l|}
\hline $\begin{array}{l}\text { Not at all } \\
\text { useful }\end{array}$ & $\begin{array}{l}\text { Not very } \\
\text { useful }\end{array}$ & $\begin{array}{l}\text { Neither not } \\
\text { useful nor } \\
\text { useful }\end{array}$ & $\begin{array}{l}\text { Somewhat } \\
\text { useful }\end{array}$ & Very useful & N/A \\
\hline
\end{tabular}

Your reasons for this rating:

Simulation based, interprofessional learning

\begin{tabular}{|l|l|l|l|l|l|}
\hline $\begin{array}{l}\text { Not at all } \\
\text { useful }\end{array}$ & $\begin{array}{l}\text { Not very } \\
\text { useful }\end{array}$ & $\begin{array}{l}\text { Neither not } \\
\text { useful nor } \\
\text { useful }\end{array}$ & $\begin{array}{l}\text { Somewhat } \\
\text { useful }\end{array}$ & Very useful & N/A \\
\hline
\end{tabular}

Your reasons for this rating:

Team based approaches tailored to primary health care/general practice

\begin{tabular}{|l|l|l|l|l|l|}
\hline $\begin{array}{l}\text { Not at all } \\
\text { useful }\end{array}$ & $\begin{array}{l}\text { Not very } \\
\text { useful }\end{array}$ & $\begin{array}{l}\text { Neither not } \\
\text { useful nor } \\
\text { useful }\end{array}$ & $\begin{array}{l}\text { Somewhat } \\
\text { useful }\end{array}$ & Very useful & N/A \\
\hline
\end{tabular}

Your reasons for this rating:

Issue/problem based interprofessional learning

\begin{tabular}{|l|l|l|l|l|l|}
\hline $\begin{array}{l}\text { Not at all } \\
\text { useful }\end{array}$ & $\begin{array}{l}\text { Not very } \\
\text { useful }\end{array}$ & $\begin{array}{l}\text { Neither not } \\
\text { useful nor } \\
\text { useful }\end{array}$ & $\begin{array}{l}\text { Somewhat } \\
\text { useful }\end{array}$ & Very useful & N/A \\
\hline
\end{tabular}

Your reasons for this rating:

Case based interprofessional learning

\begin{tabular}{|l|l|l|l|l|l|}
\hline $\begin{array}{l}\text { Not at all } \\
\text { useful }\end{array}$ & $\begin{array}{l}\text { Not very } \\
\text { useful }\end{array}$ & $\begin{array}{l}\text { Neither not } \\
\text { useful nor } \\
\text { useful }\end{array}$ & $\begin{array}{l}\text { Somewhat } \\
\text { useful }\end{array}$ & Very useful & N/A \\
\hline
\end{tabular}

Your reasons for this rating:

Student-led case conferencing

Journal of Research in Interprofessional Practice and Education

Vol. 6.1

June 2016

\begin{tabular}{|l|l|l|l|l|l|}
\hline $\begin{array}{l}\text { Not at all } \\
\text { useful }\end{array}$ & $\begin{array}{l}\text { Not very } \\
\text { useful }\end{array}$ & $\begin{array}{l}\text { Neither not } \\
\text { useful nor } \\
\text { useful }\end{array}$ & $\begin{array}{l}\text { Somewhat } \\
\text { useful }\end{array}$ & Very useful & N/A \\
\hline
\end{tabular}

Your reasons for this rating: 


\section{JRIPE}

Delphi Technique in Interprofessional Training

Bentley, Kerr, \& Powell

Journal of Research in Interprofessional Practice and Education

\section{Journal of Research in Interprofessional Practice and Education}

\section{Appendix 2 (cont.)}

Clinical audits as a mechanism for interprofessional learning

\begin{tabular}{|l|l|l|l|l|l|}
\hline $\begin{array}{l}\text { Not at all } \\
\text { useful }\end{array}$ & $\begin{array}{l}\text { Not very } \\
\text { useful }\end{array}$ & $\begin{array}{l}\text { Neither not } \\
\text { useful nor } \\
\text { useful }\end{array}$ & $\begin{array}{l}\text { Somewhat } \\
\text { useful }\end{array}$ & Very useful & N/A \\
\hline
\end{tabular}

Your reasons for this rating:

Any other comments on this section?

\section{Section 4: Organisation - the where?}

This section covers institutional delivery for interprofessional education and training.

Lecture/seminar based education and training sessions

\begin{tabular}{|l|l|l|l|l|l|}
\hline $\begin{array}{l}\text { Not at all } \\
\text { important }\end{array}$ & Unimportant & $\begin{array}{l}\text { Neither } \\
\text { unimportant } \\
\text { nor important }\end{array}$ & Important & $\begin{array}{l}\text { Very } \\
\text { important }\end{array}$ & N/A \\
\hline
\end{tabular}

Your reasons for this rating:

\section{Team based education and training}

Interprofessional teams need to be collocated to function effectively

\begin{tabular}{|l|l|l|l|l|l|}
\hline $\begin{array}{l}\text { Strongly } \\
\text { disagree }\end{array}$ & Disagree & $\begin{array}{l}\text { Neither agree } \\
\text { nor disagree }\end{array}$ & Agree & $\begin{array}{l}\text { Strongly } \\
\text { agree }\end{array}$ & N/A \\
\hline
\end{tabular}

Your reasons for this rating:

Clarity on the role of leadership in an interprofessional team is critical for effective team functioning

\begin{tabular}{|l|l|l|l|l|l|}
\hline $\begin{array}{l}\text { Strongly } \\
\text { disagree }\end{array}$ & Disagree & $\begin{array}{l}\text { Neither agree } \\
\text { nor disagree }\end{array}$ & Agree & $\begin{array}{l}\text { Strongly } \\
\text { agree }\end{array}$ & N/A \\
\hline
\end{tabular}

Your reasons for this rating:

\section{Virtual learning spaces}

Virtual communities of practice can overcome isolation for primary health care practitioners in rural and remote areas.

\begin{tabular}{|l|l|l|l|l|l|}
\hline $\begin{array}{l}\text { Strongly } \\
\text { disagree }\end{array}$ & Disagree & $\begin{array}{l}\text { Neither agree } \\
\text { nor disagree }\end{array}$ & Agree & $\begin{array}{l}\text { Strongly } \\
\text { agree }\end{array}$ & N/A \\
\hline
\end{tabular}

Your reasons for this rating: 


\section{JRIPE \\ Journal of Research in Interprofessional Practice and Education}

\section{Appendix 2 (cont.)}

Delphi Technique in Interprofessional Training

Bentley, Kerr, \& Powell

Internet-based courses can provide meaningful interaction for primary health care practitioners.

\begin{tabular}{|l|l|l|l|l|l|}
\hline $\begin{array}{l}\text { Strongly } \\
\text { disagree }\end{array}$ & Disagree & $\begin{array}{l}\text { Neither agree } \\
\text { nor disagree }\end{array}$ & Agree & $\begin{array}{l}\text { Strongly } \\
\text { agree }\end{array}$ & N/A \\
\hline
\end{tabular}

Your reasons for this rating:

\section{What else is needed?}

A central training calendar for primary health care/general practice

\begin{tabular}{|l|l|l|l|l|l|}
\hline $\begin{array}{l}\text { Not at all } \\
\text { important }\end{array}$ & Unimportant & $\begin{array}{l}\text { Neither } \\
\text { unimportant } \\
\text { nor important }\end{array}$ & Important & $\begin{array}{l}\text { Very } \\
\text { important }\end{array}$ & N/A \\
\hline
\end{tabular}

Your reasons for this rating:

A central directory of educators and supervisors for interprofessional primary health care training

\begin{tabular}{|l|l|l|l|l|l|}
\hline $\begin{array}{l}\text { Not at all } \\
\text { important }\end{array}$ & Unimportant & $\begin{array}{l}\text { Neither } \\
\text { unimportant } \\
\text { nor important }\end{array}$ & Important & $\begin{array}{l}\text { Very } \\
\text { important }\end{array}$ & N/A \\
\hline
\end{tabular}

Your reasons for this rating:

Any other comments on this section?

Journal of Research in Interprofessional Practice and Education

Vol. 6.1

June 2016

www.jripe.org 


\section{JRIPE}

Delphi Technique in Interprofessional Training

Bentley, Kerr, \& Powell

Journal of Research in Interprofessional Practice and Education

Vol. 6.1

June 2016

\section{Appendix 3}

\author{
Integrated Roadmap to Best Practice Training in Primary Health Care \\ Training in Tasmania (Round 3)
}

\section{Integrated Roadmap to Best Practice Training in Primary Health Care Training in Tasmania}

\author{
Round 3
}

In Round 3 (the final round), we are asking you to rate and comment on the statements where there was no clear consensus in Round 2 [Consensus defined as a Median Score $=4$ or more AND Agreement $=70 \%$ or more]. Selected comments from Round 2 are included with these statements.

The statements are grouped under four sections:

1. Big picture (the why?)

2. Capabilities (the what?)

3. Teaching \& Learning (the how?)

4. Organisation (the where?)

There are 8 statements to rate. If you have no opinion on a statement, please tick the N/A box.

There are also 11 questions on the focus areas for interprofessional education for collaborative practice.

\section{Section 1: Big picture decisions - the why?}

This section covers the context of health practice needs in Tasmania.

The panel did not reach consensus on whether more evidence is needed on the organisational and systemic determinants of interprofessional education for collaborative practice.

Median score=4; Agreement=64\%; Disagreement=12\%

The most recent Cochrane Review concludes: "More studies are needed to allow sound conclusions to be reached about the effectiveness of IPE, as well as to inform IPE policy development" [1]. However, a review of evaluations of IPE found that IPE is highly contextual and is an important mechanism in the development of practice and improvement of services [2].

[1] Reeves, S. et al. Interprofessional education: effects on professional practice and healthcare outcomes (update). Cochrane Database of Systematic Reviews 2013. Issue 3. Art. No. CD002213.

[2] Hammick, M. et al. A best evidence systematic review of interprofessional education: BEME Guide no. 9. Medical Teacher 2007, 29: 735751. 


\section{JRIPE}

36

Delphi Technique in Interprofessional Training

Bentley, Kerr, \& Powell

More evidence is needed on the organisational and systemic determinants of interprofessional education for collaborative practice

\begin{tabular}{|l|l|l|l|l|}
\hline $\begin{array}{l}\text { Strongly } \\
\text { disagree }\end{array}$ & Disagree & Agree & $\begin{array}{l}\text { Strongly } \\
\text { agree }\end{array}$ & N/A \\
\hline
\end{tabular}

The next 4 statements relate to barriers to interprofessional education for collaborative practice in Tasmania

The panel did not reach consensus on whether the curriculum at the University of Tasmania is too crowded to expand interprofessional education for primary health.

Median score=3; Agreement=24\%; Disagreement=33\%

The curriculum at the University of Tasmania is too crowded to expand interprofessional education for primary heath.

\begin{tabular}{|l|l|l|l|l|}
\hline $\begin{array}{l}\text { Strongly } \\
\text { disagree }\end{array}$ & Disagree & Agree & $\begin{array}{l}\text { Strongly } \\
\text { agree }\end{array}$ & N/A \\
\hline
\end{tabular}

Your reasons for this rating:

The panel did not reach consensus of whether the lack of undergraduate Allied Health education at the University of Tasmania limits opportunities for interprofessional education.

Median score=4; Agreement $=64 \%$; Disagreement $=17 \%$

The lack of undergraduate Allied Health education at the University of Tasmania limits opportunities for interprofessional education.

\begin{tabular}{|l|l|l|l|l|}
\hline $\begin{array}{l}\text { Strongly } \\
\text { disagree }\end{array}$ & Disagree & Agree & $\begin{array}{l}\text { Strongly } \\
\text { agree }\end{array}$ & N/A \\
\hline
\end{tabular}

The panel did not reach consensus on whether the lack of postgraduate training in Tasmania for some disciplines limits opportunities for interprofessional education.

Median score=4; Agreement=64\%; Disagreement=17\%

The lack of postgraduate training in Tasmania for some disciplines limits opportunities for interprofessional education.

Journal of Research in Interprofessional Practice and Education

Vol. 6.1

June 2016

\begin{tabular}{|l|l|l|l|l|}
\hline $\begin{array}{l}\text { Strongly } \\
\text { disagree }\end{array}$ & Disagree & Agree & $\begin{array}{l}\text { Strongly } \\
\text { agree }\end{array}$ & N/A \\
\hline
\end{tabular}

Your reasons for this rating: 
Delphi Technique in Interprofessional Training

Bentley, Kerr, \& Powell
The panel did not reach consensus on whether existing requirements for continuing professional development limit opportunities for interprofessional training.

Median score $=3$; Agreement $=26 \%$, Disagreement $=38 \%$

Existing requirements for continuing professional development limit opportunities for interprofessional training.

\begin{tabular}{|l|l|l|l|l|}
\hline $\begin{array}{l}\text { Strongly } \\
\text { disagree }\end{array}$ & Disagree & Agree & $\begin{array}{l}\text { Strongly } \\
\text { agree }\end{array}$ & N/A \\
\hline
\end{tabular}

Your reasons for this rating:

\section{Section 2: Defining and understanding capabilities - the what?}

This section covers knowledges, competencies, capabilities for interprofessional education and training.

The three main priority focus areas where interprofessional education for collaborative practice is needed are: mental health (83\%), chronic conditions (83\%), and caring for an ageing population (73\%).

Aboriginal health, Lesbian, Gay, Bisexual, Transgender, Intersex health, Refugee health, Women's and Children's health, and Youth health are all still important.

Other areas where interprofessional education for collaborative practice is needed are emergency medicine, musculoskeletal conditions, pain, use of medicines, wound management, and leadership.

- What interprofessional education is needed for collaborative practice in mental health?

- What interprofessional education is needed for collaborative practice in chronic conditions?

- What interprofessional education is needed for collaborative practice in caring for an ageing population?

- What interprofessional education is needed for collaborative practice in Aboriginal health?

- What interprofessional education is needed for collaborative practice in Lesbian, Gay, Bisexual, Transgender, Intersex health?

- What interprofessional education is needed for collaborative practice in Refugee health?

- What interprofessional education is needed for collaborative practice in Women's and Children's health?

- What interprofessional education is needed for collaborative practice in Youth health?

- What interprofessional education is needed for collaborative practice in Emergency Medicine?

- What interprofessional education is needed for collaborative practice in musculoskeletal conditions/Pain?

Journal of Research in Interprofessional Practice and Education

Vol. 6.1

June 2016
- What interprofessional education is needed for collaborative practice in Use of Medicines?

- What interprofessional education is needed for collaborative practice in wound management?

- What interprofessional education in needed for leadership in collaborative practice? 


\section{JRIPE}

Delphi Technique in Interprofessional Training

Bentley, Kerr, \& Powell

\section{Appendix 3 (cont.)}

\section{Section 3: Teaching and learning - the how?}

This section covers approaches and practices to teaching and learning.

The panel did not reach consensus on whether student-led case conferencing is a useful mode of interprofessional learning.

Median score=4; 68\% Agreement.

The literature defines student-led case conferencing as "student-led sessions where students from more than one health profession have been on clinical placement in the same area and have undertaken to present a patient case study for discussion" [1].

Successful student leadership in IPE ... requires the support of educators, researchers and policymakers in fostering an enabling environment that will facilitate the efforts and contributions of student leaders [2].

[1] Stew, G. Learning together in practice: a survey of interprofessional education in clinical settings in South-East England. Journal of Interprofessional Care, 2005; 19(3), p. 227.

[2] Hoffman, S.J. et al. Student leadership in interprofessional education: benefits, challenges and implications for educators, researchers and policymakers. Medical Education, 2008; 42(7), p. 654.

Student-led case conferencing is a useful mode of interprofessional learning for primary health care professionals.

\begin{tabular}{|l|l|l|l|l|}
\hline $\begin{array}{l}\text { Not at all } \\
\text { useful }\end{array}$ & $\begin{array}{l}\text { Not very } \\
\text { useful }\end{array}$ & $\begin{array}{l}\text { Somewhat } \\
\text { useful }\end{array}$ & Very useful & N/A \\
\hline
\end{tabular}

Your reasons for this rating:

\section{Section 4: Organisation - the where?}

This section covers institutional delivery for interprofessional education and training.

The panel did not reach consensus on whether lecture/seminar based education and training sessions are important for interprofessional education and training.

Median score=4; Agreement $=67 \%$

\section{Lecture/seminar based education and training sessions}

Journal of Research in Interprofessional Practice and Education

\begin{tabular}{|l|l|l|l|l|}
\hline $\begin{array}{l}\text { Not at all } \\
\text { useful }\end{array}$ & $\begin{array}{l}\text { Not very } \\
\text { useful }\end{array}$ & $\begin{array}{l}\text { Somewhat } \\
\text { useful }\end{array}$ & Very useful & N/A \\
\hline
\end{tabular}

Your reasons for this rating: 


\section{JRIPE \\ Journal of Research in Interprofessional Practice and Education}

\section{Appendix 3 (cont.)}

Delphi Technique in Interprofessional Training

Bentley, Kerr, \& Powell

The panel just reached consensus on whether interprofessional teams need to be collocated to function effectively (Median score=4; Agreement=70\%) but there was some disagreement and uncertainty.

Interprofessional teams need to be collocated to function effectively.

\begin{tabular}{|l|l|l|l|l|}
\hline $\begin{array}{l}\text { Strongly } \\
\text { disagree }\end{array}$ & Disagree & Agree & $\begin{array}{l}\text { Strongly } \\
\text { agree }\end{array}$ & N/A \\
\hline
\end{tabular}

Your reasons for this rating: 